\title{
Gender and Opinion-Policy Congruence in Europe
}

\begin{abstract}
In a well-functioning democracy, public policy should not systematically reflect the preferences of some groups of citizens less well than those of others. Yet, it is often believed that this is the case for women, with one potential reason being their lower presence in politics. However, we lack systematic empirical evidence on the representation of women's and men's preferences in concrete policy. This study provides such evidence for a diverse set of twenty specific policy issues in 31 European countries. While the majorities of men and women often desire the same policies, men's preferences are more likely to be represented when they disagree. This pattern can neither be explained by the proportion of women in parliament nor by the left-right position of the government. In contrast, a higher effective number of political parties increases women's relative representation, while electoral system proportionality does not. 'New politics' issues play a key role here, but differences in women's representation do not seem to be due to presence of Green parties and government positions on the libertarian-authoritarian dimension.
\end{abstract}




\section{INTRODUCTION}

One of the main principles and goals of representative democracy is that policy ought to - at least roughly - reflect citizens' preferences. It is what Hanna Pitkin (1967) termed 'substantive representation'. Policy representation is certainly not the only criterion for judging the quality of democracy, and in cases where it is in tension with government responsibilities or fundamental human rights a closer link between the majority opinion and policy may even be undesirable. Yet, it is an important indicator of whether 'government by the people' is functioning, and one that has received growing attention from political scientists (e.g. Lax and Phillips 2012; Monroe 1998; Soroka and Wlezien 2010). Citizens also seem to care, as they evaluate the quality of their democratic system based on how well they are represented (e.g. Ezrow and Xezonakis 2010; Reher 2015).

However, modern democracies have a problem not only if policy is out of step with the preferences of the people, but also if grave inequalities exist in the representation of the views of different social groups. As Sidney Verba (2003: 663) states, "one of the bedrock principles in a democracy is the equal consideration of the preferences and interests of all citizens". Consequently, a growing number of studies investigate whether disparities exist in the representation of different social groups, the majority of which focus on the rich and the poor (e.g. Bartels 2008; Bernauer et al. 2015; Brunner et al. 2013; Gilens 2012; Peters and Ensink 2015; Soroka and Wlezien 2008).

This study focuses on a societal group that is underrepresented in politics up to this day: women. They hold fewer seats in parliaments and posts in governments across the world, including the most advanced democracies. This might have consequences for the degree to which policy reflects the views of women, since it is often argued that women may be better at representing women (Mansbridge 1999; Phillips 1995). Several studies suggest that women's 
numerical or 'descriptive' representation (Pitkin 1967) and the degree to which their interests are reflected in politics are indeed linked (e.g. Bratton and Ray 2002; Kittilson 2008; SchwindtBayer and Mishler 2005). However, despite this research we know relatively little about how well the policies in place actually align with the views of women as compared to men.

The first aim of this study is to extend our knowledge about the existence of gender inequality in substantive representation in Europe by assessing how well the preferences of women and men are reflected in public policy across a wide variety of domains. The study draws on public opinion data from major cross-national surveys on a diverse set of 20 specific issues in 31 European countries, matched with information on policy collected from a range of governmental, academic, interest group, and media sources. This data shows that the majorities of women and men prefer the same policy in an overwhelming majority of cases. Interestingly, women and men strongly agree on issues typically regarded as 'women's issues', whereas most disagreement exists on 'new politics' issues. Importantly, the findings provide evidence for a gender gap in representation: in those cases where women and men disagree, policy is more likely to reflect the preferences of men.

The second aim of the study is to investigate what might explain these differences. Interestingly, neither the proportion of women in parliament nor the left-right position of the government appear to affect whether policy is congruent with the preferences of women or men, despite large literatures showing that women tend to be more left-wing (e.g. Bergh 2007; Campbell 2004; Gidengil et al. 2003; Bernauer et al. 2015) and that the female legislators are more likely to promote women's rights and interests (e.g. Bratton and Haynie 1999; Campbell et al. 2010; Celis 2006; Swers 1998; Taylor-Robinson and Heath 2003; Thomas 1991; Vega and Firestone 1995). 
In contrast, a higher number of parliamentary parties does seem to improve women's representation. This holds when controlling for the proportionality of the electoral system as well as women's descriptive representation, which has been shown to be strongly affected by electoral rules (e.g. Matland and Studlar 1996). The effect might be due to small parties placing issues on the agenda which have received less attention from the mainstream parties but appear to be the major point of contention between men and women. However, neither the government position on the libertarian-authoritarian dimension nor the presence of Green parties can explain women's policy congruence. The effect of the number of parties might thus be due to other institutions and practices introduced by parties which benefit the representation of women's opinions. In addition to providing important novel evidence on the state of gender equality in policy representation in Europe, the study thus provides an agenda for further research into the explanations of women's representation.

\section{GENDER AND REPRESENTATION}

Although the number of women in politics has increased over the last decades, they are still in the minority in parliaments across Europe (Figure 1). While women hold 44 per cent of the seats in the Swedish parliament, the European average is much lower with 29 per cent, and in Hungary only 10 per cent of parliamentarians are women. This raises the question whether women's views are also underrepresented in the output of the political process, meaning the laws that govern European societies. It is somewhat surprising that we have not yet answered this question. A few studies have assessed different aspects of women's policy representation in Europe. Homola (2017) shows that although the manifestos of European parties respond to shifts in the left-right positions of both genders, they seem to be more responsive to men. Yet, this does not necessarily result in unequal representation in parliament: as Bernauer, Giger and Rosset (2015) show, 
women tend to be more left-leaning but are not consistently further away from the most proximate parliamentary party than men.

\section{[FIGURE 1 AROUND HERE]}

Although representation in terms of political ideology is undoubtedly important, neither parties' nor citizens' positions on specific policy issues always neatly align with the left-right dimension or even several ideological dimensions (e.g. Converse 1964; Dolezal et al. 2013). We should therefore also examine how well the public is represented on more narrow issues and in concrete policy outcomes (Thomassen 2012). So far, this strategy has mostly been employed in studies of the representation of income groups (e.g. Brunner et al. 2013; Gilens 2012; Soroka and Wlezien 2008) and of the overall public (e.g. Lax and Phillips 2012; Monroe 1998; Page and Shapiro 1983). In the context of gender, a recent study by Dingler, Kroeber and Fortin-Rittberger (2018) investigates whether inequalities exist in the congruence between public opinion and the positions of parliaments around Europe, measured by expert placements of parties on seven policy dimensions. Interestingly, they find that women's views are overall better represented than men's. Outside of Europe, an analysis of roll-call votes in the US House of Representatives by Griffin, Newman and Wolbrecht (2012) reveals that the underrepresentation of women's views in districts represented by Republicans is counterbalanced by their better representation in Democratic districts.

While these studies look beyond left-right ideology, their results still do not tell us how well women's preferences are reflected in actual policy. First, rather than parliaments as a whole, it is primarily governments which determine which policies are put into place. Yet, analyzing government positions is still not sufficient since they cannot always implement their preferences: they need to prioritize among issues, bargain with coalition partners, overcome institutional hurdles, and react to events, changing economic conditions etc. It is possible that these 'frictions' 
(e.g. Baumgartner et al. 2009; Bevan and Greene 2016) introduce biases in the policy-making process that result in policies that are less reflective of women's preferences than men's, even if no gender inequalities exist in the positions of parliaments and governments. By looking at women's and men's support of implemented policies, this study thus extends our knowledge of women's representation in Europe to a further stage of the representation process.

Hypothesis 1: Public policy is less congruent with the preferences of women than the preferences of men across Europe.

\section{EXPLAINING WOMEN'S POLICY CONGRUENCE}

The second objective of this study is to examine what might explain gender differences in policy representation across Europe. While there are a range of potentially important variables, the focus here is on three political factors: women's descriptive representation, the ideology of the government, and electoral and party systems.

\section{Descriptive representation}

As Anne Phillips (1995) famously contended, women's presence in politics will in certain contexts strengthen their substantive policy representation, since they have some (largely though not universally) shared interests and experiences that are not shared by men. These interests and experiences give rise to policy preferences which women will be more likely to promote due to their higher awareness and commitment (cf. also Mansbridge 1999). A vast number of studies have empirically examined this argument from different angles (Wängnerud 2009). Women legislators tend to place stronger emphasis on issues related to women, children, and family (Thomas 1991, 1994), support social welfare (Poggione 2004; Wängnerud 2000), and promote 
women's rights and gender equality (Bratton and Haynie 1999; Campbell et al. 2010; Celis 2006; Swers 1998; Taylor-Robinson and Heath 2003; Thomas 1991; Vega and Firestone 1995). These differences are to a large degree mirrored in the public (Thomas 1994; Wängnerud 2000). Parties with more women MPs also address greater sets of issues and become more left-leaning (Greene and O’Brien 2016).

On the other hand, parliaments with high numbers of women are neither necessarily nor exclusively 'gender-sensitive parliaments' (Wängnerud 2015). Political parties play a crucial role by conditioning how gender shapes legislators' attitudes and actions (e.g. Osborn 2012; Poggione 2004) and even overshadowing its role (e.g. Esaiasson and Holmberg 1996; Swers 1998). Qualitative studies by Sawer (2012) and Childs and Withey (2006) elucidate the importance of individual or small groups of women who become 'critical actors' (cf. Childs and Krook 2009) as well as of specific networks and institutions. Others emphasize the importance of cabinets (e.g. Atchison 2015) or women's movements and policy agencies (e.g. Htun and Weldon 2012; Weldon 2002; Stetson and Mazur 1995) as key arenas beyond parliaments in which women promote their interests.

Reflecting this disagreement about the impact of women's 'mere' presence in parliaments on policy outcomes, the studies that have tested this relationship arrive at varying conclusions. In the US, Thomas (1991) shows that the proportion of women in state legislatures is unrelated to the passage of bills linked to women, children, or families. Griffin, Newman and Wolbrecht (2012) find that women are not better represented by female representatives. In contrast, Schwindt-Bayer and Mishler (2005) observe effects of women's descriptive representation on maternity leave, marriage equality laws, and political and social gender equality. Kittilson (2008) finds effects on parental leave across postindustrial democracies and Bratton and Ray (2002) on 
municipal child care in Norway. Meanwhile, mixed effects have been found in Swedish local councils (Wängnerud and Sundell 201) and in the Argentine Congress (Htun et al. 2013).

While these studies provide important insights, most of them focus on a specific set of policies or measures of gender equality and do not empirically assess women's and men's preferences. Usually, this approach reflects a deliberate decision to study the representation of women's interests through the promotion 'feminist policy' (Mazur 2002). These interests are derived not from expressed preferences but from women's distinct experiences and the goals of women's rights and equal status (Phillips 1995; Waylen 2007). The study presented here pursues a different objective, namely to assess the degree to which the expressed preferences of women and men are reflected in policy. This aim calls for an empirical examination of the views of both women and men across a wide variety of policy issues, for at least two reasons.

First, women and men have a range of identities beyond their gender (cf. Campbell et al. 2010; Childs and Withey 2006: 11). This means that their preferences are likely heterogeneous (for instance, many women are opposed to abortion (cf. Shapiro and Mahajan 1986)) and might often be very similar to men's. Moreover, these patterns are likely to vary across contexts. Second, women and men might disagree substantially on policy issues that are not usually considered 'women's issues', meaning that some inequalities might have gone unnoticed. This study addresses both issues by measuring women's and men's preferences on a diverse range of policy issues. Using a similar framework, Dingler and colleagues (2018) find no effect of descriptive representation on women's relative congruence with parliaments' issue positions. Yet, as discussed above, comparing women's and men's views with concrete policy might yield different conclusions. 
Hypothesis 2: Larger proportions of women in national parliaments are associated with higher levels of congruence between public policy and the preferences of women relative to those of men.

\section{Government ideology}

While women had traditionally been more conservative in their views and voting behavior in most Western democracies, these patterns reversed in the last two decades of the twentieth century through a 'realignment' that led to the 'modern gender gap' (Inglehart and Norris 2000).

Several explanations have been proposed for why women now tend to hold more left-wing attitudes (Campbell 2004; Gidengil et al. 2003; Bernauer et al. 2015) and show stronger support for left-wing parties (see also Bergh 2007). First, their lower salary and higher poverty levels, their greater reliance public services such as childcare and social care services as well as their higher degree of public sector employment might make them more supportive of the welfare state and public spending (Inglehart and Norris 2000; Knutsen 2001; Gidengil et al. 2003; but see Bergh 2007).

Second, the greater support for feminist ideas and equality more generally that left-wing parties tend to display might attract more voters with a 'feminist consciousness' (Hayes 1997). Finally, some studies claim that differences in policy preferences have socio-psychological origins. Men's higher support for military programs may be rooted in social dominance orientation, which implies a stronger preference for inequality among social groups (Pratto et al. 1997). Differences in economic attitudes, with women being less individualistic and trusting in the market, might be partially explained by moral reasoning (Gidengil et al. 2003).

Regardless of their roots, these observed patterns lead us to expect that policy reflects women's views better under more left-wing governments. Yet, the existing evidence on this 
relationship is mixed. Griffin et al. (2012) demonstrate that women's preferences are better reflected in US Congress roll-call votes when the Democrats are in the majority. Wängnerud and Sundell (2012) find that while some outcomes for women are better in Swedish municipalities with left-green coalitions, others are not. Meanwhile, Kittilson (2008) finds no effect of left party power in government on family leave policy. These discrepancies are likely due to the different contexts and measures of women's interests. Testing the relationship in a cross-national and multi-issue framework will shed further light on this question.

Hypothesis 3: More left-wing governments are associated with higher levels of congruence between public policy and the preferences of women relative to those of men.

\section{Electoral rules and party systems}

Electoral systems play an important role in women's representation: more proportional electoral rules - particularly higher district magnitudes and numbers of parliamentary parties as well as lower electoral thresholds - are linked to higher numbers of women in parliament (Matland and Studlar 1996; Matland and Taylor 1997; McAllister and Studlar 2002; Rule 1987). Thus, if descriptive representation affects substantive representation, we would expect women's preferences to be better represented in more proportional systems. However, electoral rules might also influence women's policy representation through other channels, which have received much less attention (cf. Krook and Schwindt-Bayer 2013: 569; Schwindt-Bayer and Mishler 2005: 412).

Two mechanisms have been proposed in this context. The first involves differences in the tendency of female politicians to represent women. Female politicians might be more likely to consider it their responsibility to represent women if they were elected via party lists in PR systems, where representation is not strongly tied to geographical constituencies like in single- 
member district systems (Höhmann 2017; Tremblay 2003). As a result, we might expect women's preferences to be more equally represented in PR systems, even when holding the number of women in parliament constant.

Hypothesis 4a: Proportional electoral systems are associated with higher levels of congruence between public policy and the preferences of women relative to those of men than majoritarian systems.

The second potential effect of electoral rules is through the number of parties. More proportional rules make it easier for smaller, and hence more, parties to enter parliament (Cox 1997). As new parties are incentivized to adopt positions which are held by significant numbers of voters but not by any party, a higher number of parties extends the coverage of the political spectrum (Blais and Bodet 2006; Golder and Stramski 2010). As Bernauer, Giger and Rosset (2015) argue, this should translate into a better representation of different groups of voters, including women, by the parties in parliament. Through the more frequent occurrence of coalition governments in multi-party systems, this representation could then be translated into policy output.

Although Bernauer et al. (2015) do not find support for such an effect with regard to women's congruence with party ideology, we might find it in a multi-dimensional policy space. Women often hold different policy priorities from men; importantly, they tend to focus less on economic issues that are traditionally associated with the left-right dimension (Campbell 2004; Wängnerud 2000). This implies that women might more often desire policy on issues to which mainstream parties pay less attention. A higher number of parties in parliament might make it more likely that at least one party focuses on these issues. This could be women's parties, which are rare but present in some contexts in Europe, but also other 'niche parties' which "politicize 
sets of issues which were previously outside the dimensions of party competition" (Meguid 2005: 347; see also Wagner 2012). Even if not in government, these parties may influence the policy agenda and incentivize other parties to pass (or maintain) policy in line with women's policy preferences (cf. Abou-Chadi 2016; Cowell-Meyers 2011, 2017; de Vries and Hobolt 2012).

Another potential mechanism through which higher numbers of parties might improve women's representation involves contagion effects. As Matland and Studlar (1996) argue, if one party starts nominating more women, others are likely to follow suit (see also Caul 2001 on gender quotas). The higher the numbers of parties, the higher the probability that a party promoting women's descriptive representation exists. Similar contagion effects might be at work with respect to practices and institutions other than the nomination of women which might improve their substantive representation in policy (cf. Kittilson 2013). For instance, multi-party systems may be more likely to include parties that give more powerful positions to women, have women's sections, or require gender equity with regard to speaking time. The other parties may then be motivated or pressured to pick up similar practices and institutions (Matland and Studlar 1996). In sum, there are several reasons for why we might expect the number of parties in parliament to be associated with stronger policy congruence among women.

Hypothesis 4b: Higher numbers of parliamentary parties are associated with higher levels of congruence between public policy and the preferences of women relative to those of men.

\section{DATA AND METHOD}

I analyze women's and men's policy representation using a dataset that includes measures of public opinion and policy status for twenty policy issues in 31 European countries. The public opinion data comes from eighteen cross-national opinion surveys conducted between 1998 and 
2013 which cover at least fifteen European countries (Eurobarometer, International Social Survey Programme, European Election Study, European Values Study, and European Social Survey). Among all items that ask about a specific policy and fulfil several criteria (they must concern concrete policies rather than broader issue areas, ask about agreement with policies rather than desired changes in policy, and be within the competence of the national government), twenty policy items were selected so as to cover a large variety of policy areas (see Table S1 in the SI). Overall, the sample contains 491 issue-country observations. The issues vary in salience (Figure S1), measured by the relative number of articles that address the policy issue in the Financial Times coverage of Europe over a period of three years, starting two years before the respective survey was conducted. Selecting issues from surveys independently from whether they have been on the political or public agenda is important for avoiding overestimating representation levels, which have been found to be higher on more salient issues (e.g. Monroe 1998; Page and Shapiro 1983). The most salient issue is nuclear power, the least salient one concerns warnings for pregnant women and drivers on alcohol bottles.

Public support for a policy is measured as the percentage of respondents who indicated support among all those who were either in favor or against the policy, excluding respondents who replied with 'don't know' or 'neither in favor nor against' (see Table S2 for descriptive statistics). After compiling the set of policy issues from the public opinion surveys, it was determined whether or not a policy was in place in a country at the time when the survey was conducted (cf. Brooks 1990; Lax and Phillips 2012; Monroe 1998 for similar procedures). This was determined on the basis of relevant legal documents, publications by national governmental and EU bodies, academic publications, newspaper articles, publications by interest groups and 
non-governmental organizations, and expert interviews. ${ }^{1}$ The binary indicator of whether a policy was in place was then used to construct a dichotomous measure of congruence between the preferences of the majority (of women, men or the entire public) and the policy in place. The congruence variable takes the value 1 if the majority was in favor of the policy and the policy was in place, or if the majority was against it and it was not in place, while 0 indicates that public opinion and policy were not aligned.

By measuring public opinion and policy status at the same point in time, this study analyzes the representation of public opinion in policy rather than (dynamic) policy responsiveness (e.g. Page and Shapiro 1983; Peters and Ensink 2015; Soroka and Wlezien 2010; Stimson et al. 1995). The approach is equivalent or similar to those of other studies of congruence of public opinion with policy (Rasmussen et al. 2018) and party positions (e.g. Bernauer et al. 2015; Blais and Bodet 2006; Dingler et al. 2018; Golder and Stramski 2010). It reflects the idea that policy representation may come about in a variety of ways: not only through policy-makers responding to public opinion, but also through concurrent reactions of policymakers and citizens to events or developments or through public opinion formation 'from above', where the public adjusts its preferences to policy (cf. Esaiasson and Holmberg 1996; Kuklinski and Segura 1995). Indeed, one of the main tasks of political representatives is providing the public with information about policy issues and explain their reasons for (not) taking certain actions. This means that gender disparities in congruence might not only be a result of unequal policy responsiveness but also of gender imbalances in political elites' justification and persuasion efforts.

\footnotetext{
${ }^{1}$ The process of collecting data on policy and constructing the binary indicator is described in the Supplementary Information B.
} 


\section{Independent variables}

The descriptive representation of women is measured by the mean proportion of women in the national parliament (single or lower chamber) over four years ( $t-3$ to $t)$, based on data from the Inter-Parliamentary Union (IPU 2018). Government ideology is the average of the mean positions of the cabinet parties (weighted by seat share) on the left-right dimension provided by the Chapel Hill Expert Survey (Bakker et al. 2015) over the previous four years. The scale ranges from $0-10$, with higher values indicating more right-wing positions. To test the hypotheses about electoral systems, I use a dummy variable indicating whether the majority of lower house seats is allocated through PR or plurality rules (Keefer 2015). I test the robustness of the results with the Gallagher Index indicating the degree of vote-seat disproportionality at the last legislative election (Gallagher 2014) and with the average district magnitude at the first tier at the last legislative election (Bormann and Golder 2013). Lastly, I use Golder's (2010; Bormann and Golder 2013) measure of the Effective Number of Parliamentary Parties (ENPP) from the last legislative election prior to the year when the policy data was collected.

\section{Control variables}

The analysis controls for the degree to which women voice their opinions on a policy issue relative to men, as we might expect political elites to be more attentive to the section of the public that voices their opinions more strongly. It is the ratio of the percentage of female to that of male resopndents who expressed policy positions as opposed to 'neither nor', 'don't know', or no answer. ${ }^{2}$ Furthermore, lower turnout rates among a group might result in lower representation of

\footnotetext{
${ }^{2}$ The mean response ratios per issue are listed in Table S4.
} 
the group's views in policy - it partly explained the lower congruence of men found by Dingler and colleagues (2018). I follow Peters and Ensink (2015), who argue that turnout should be particularly unequal at low overall turnout rates and gradually equalize, and include a squared term of turnout at the last election before the previous year. I also control for democratic experience through the number of years for which a country has maintained a Polity IV score of at least +7 . Lastly, I include a year trend to account for other factors that might have led to a gradual increase in representation equality and because later years include more data from Central and Eastern Europe.

\section{RESULTS}

I start by exploring how women and men differ in their support for the twenty policies. Column (a) in Tables 1 and 2 shows the percentages of cases per issue and country, respectively, in which the majorities of women and men hold the same policy preference. The agreement levels are remarkably high: on almost half of the issues, the majorities of men and women agree on the desired direction of policy in all countries. Interestingly, they include the 'women's issues' of abortion rights and financial support for caregivers. Agreement is also very high on economic issues, while we observe most disagreement on some 'new politics' issues including nuclear power, animal rights, and adoption rights of same-sex couples. Preference agreement is remarkably high in all countries (Table 2), with the lowest levels reaching around 70 per cent in Switzerland, Belgium, and Norway. Across issues and countries, the majorities of men and women desire the same policy 87 per cent of the time. Figures S2 and S3 provide more detailed illustrations of the patterns.

[TABLES 1 AND 2 AROUND HERE] 
As we would expect based on these observations, women and men have fairly similar levels of policy congruence, as columns (b) and (c) in Tables 1 and 2 show. On average, policy reflects men's preferences 63 per cent and women's preferences 60 per cent of the time (Table 3). While evaluating these levels of congruence is somewhat difficult given the lack of clear normative expectations, they are higher than the 50 per cent which Lax and Phillips (2012) find across the US states and could be interpreted as good news for democracy in Europe. However, the picture of equality in representation changes when we focus only on the 62 cases where the majorities of women and men disagree with each other (second row in Table 3). Here, we see clear and statistically significant disparities, with men's preferences being congruent with policy 63 per cent of the time and women's in only 37 per cent of cases.

\section{[TABLE 3 AROUND HERE]}

However, we should also take the preferences of the overall majority into account (cf. Brunner et al. 2013). Representation could be considered fair if policy reflects the views of a majority of citizens. A social group can then be considered 'overrepresented' if a policy is congruent with its preference while being incongruent with the overall public. The bottom line of Table 3 shows that when the majority of men disagrees with the public majority, they get their preference 57 per cent of the time. For women, this occurs in only 33 per cent of cases. With $p=0.07$ the difference is not statistically significant by conventional standards, but we need to keep in mind that the number of cases included in this sample is quite low. Thus, the findings suggest that although women and men in Europe often hold the same policy preferences, when their views diverge women tend to be represented less often, lending support to Hypothesis $1 .^{3}$

\footnotetext{
${ }^{3}$ The Supplementary Material C provides analyses of the relationship between policy and the degree of support for it. It is stronger for men than women, providing further support for this conclusion.
} 


\section{Explaining the gender gap in policy congruence}

What explains why women or men are represented in the instances where their majorities have different policy positions? To answer this question, I regress the binary indicator of women's policy congruence on the predictors and controls. I only include the cases with majority disagreement in the analysis, which means that 1 indicates congruence with the majority of women and 0 congruence with the majority of men. Table 4 displays the results of five logistic regression models: the first four test the effect of each independent variable separately along with the controls; the fifth model includes all variables. ${ }^{4}$ Among the control variables, only year has a significant effect, though only in Model 1.

\section{[TABLE 4 AROUND HERE]}

The proportion of women in parliament is not associated with women's policy congruence in any of the model specifications. This holds when it is the only variable included and when a squared term is added to test whether a 'critical mass' of women in parliament is necessary for the effect to take hold (results not shown) (Bratton and Ray 2002; Dahlerup 1988). While this runs counter to the widely held belief that women are more likely to be represented by women, it is in line with the conclusions of several other studies (e.g. Bernauer et al. 2015; Dingler et al. 2018; Griffin et al. 2012; Thomas 1991). Similarly, we find no significant effect for the ideological position of the government. This might not be so surprising given that women and men largely agree on the economic issues that tend to be most closely associated with left and right, which are thus largely absent from the sample.

\footnotetext{
${ }^{4}$ Iceland is excluded from these analysis as it is not included in the Chapel Hill Expert Survey.
} 
Moving on to the electoral system indicators (Model 3), we find that PR and majoritarian systems do not differ in their propensity to represent women's or men's views in policy. In contrast, the higher the number of parties in parliament, the higher the chance of women's congruence as compared to men's. This statistically significant effect persists when including the other predictors (Model 5), suggesting that it does not mask an effect of electoral system proportionality and is not mediated by the proportion of women in parliament. Surprisingly, the coefficient of PR systems becomes statistically significant when controlling for the other variables, suggesting that policy is more congruent with women's preferences than men's in majoritarian systems. Yet, since neither the average district magnitude nor the Gallagher Index have a similar effect (Table S5), this finding is not extremely robust.

\section{[FIGURE 2 AROUND HERE]}

The substantive meaning of the positive coefficient of the number of parliamentary parties is illustrated in Figure 2. The average predicted probability of policy being congruent with women rather than men is at only 7 per cent in systems with effective numbers of parliamentary parties of around two, like Malta in 2010 and the UK in 2002 (the other variables are at their observed means). Women and men are equally likely to be represented in systems with around five parliamentary parties. At higher numbers of parties, policy is more likely to be congruent with women than with men, and increasingly so. However, only few countries have such high numbers of parties (see the histogram in the same figure) - the average parliament in the sample has an ENPP of 4.3, where women's probability of congruence is 34 per cent and that of men 66 per cent. ${ }^{5}$

\footnotetext{
${ }^{5}$ The significant positive effect of ENPP in Model 5 is robust to excluding the few cases with an ENPP of more than 6.
} 


\section{[TABLE 5 AROUND HERE]}

The result lends support to the proposition that parliaments with more parties are more likely to include a party that promotes policies supported by women. To explore this further, I take a closer look at the issues on which women and men disagree. As we saw earlier, these are mostly 'new politics' issues that are less strongly associated with traditional left-right politics. Table 5 shows astonishing cross-national coherence in the gendered preference patterns on these issues: on all of them, women take the same position in every country, as do men. Women show a strong tendency to favor policies championed by Green and left-libertarian parties, such as bans on nuclear energy and adoption rights for same-sex couples. Does this mean that women's higher congruence levels in contexts with more parties is due to the stronger presence and power of these types of parties?

\section{[TABLE 6 AROUND HERE]}

I test this proposition in two ways. First, I include a measure of the government position on the GAL-TAN dimension based on the Chapel Hill Expert Survey, where lower values indicate more libertarian/postmaterialist positions and higher values more traditional/authoritarian views (Bakker et al. 2015). In addition, I measure whether a Green party was represented in parliament in the previous year, based on the ParlGov data (Döring and Manow 2016). As Table 6 shows, neither of the measures affect women's policy congruence when substituted for the ENPP variable. This suggests that, rather than the presence of Green or other left-libertarian parties in multi-party systems, it could be the higher likelihood that some party represents women's preferences particularly well which explains the effect of the numbers of parliamentary parties.

\section{CONCLUSION}


Women are still in the minority in most parliaments and positions of political power across Europe and the world. But are the policies that govern societies also less reflective of the preferences of women than those of men? This study is the first to investigate this question by looking a diverse set of concrete policies across Europe. It revealed that the majorities of women and men have remarkably similar policy preferences on many issues. In these cases, policy is equally representative of the views of both genders, although the representation of one group could be 'coincidental' (cf. Enns 2015). Importantly, however, when women and men have divergent policy positions, men are more likely to see their demands fulfilled. This insight corresponds with Homola's (2017) finding of a male bias in party responsiveness, while diverging from recent findings that parliaments in Europe present women's ideological views as well as men's (Bernauer et al. 2015) and their positions on more specific policy dimensions even better (Dingler et al. 2018). These contrasting findings highlight the value of examining policy representation on various policy dimensions as well as at different stages of the policy-making process, from the drafting of election manifestos to concrete policy outcomes, at which biases might be introduced and corrected (cf. Htun et al. 2013).

In contrast to common beliefs which are based on prominent theoretical accounts (Mansbridge 1999; Phillips 1995) and backed by several studies (e.g. Bratton and Ray 2002; Kittilson 2008; Schwindt-Bayer and Mishler 2005), no effect of the proportion of women in parliament on their substantive representation in policy was found. This result, which echoes findings by Dingler et al.'s (2018) closely related study, could be seen as a further encouragement to shift our attention away from mere numbers and towards the actions of 'critical actors' and the specific institutions and structures in which they operate (cf. Childs and Krook 2009; Childs and Withey 2006; Sawer 2012). At the same time, the role of descriptive representation might be restricted to issues with particular relevance to women (e.g. Bratton and Ray 2002; Kittilson 
2008; Schwindt-Bayer and Mishler 2005; Wängnerud and Sundell 2012). Since women and men largely agreed on issues like abortion and support for caregivers, this study would not have picked up such effects. Other policy-related factors might also condition the relationship: Bratton and Ray (2002), for instance, highlight the importance of women's presence in the phase of policy innovation.

Similarly, the finding that women's relative policy congruence is not enhanced by more left-wing governments might be due to the study's focus on issues with gender disagreement, which was low on economic issues closely related to left-right ideology. Instead, women tended to be more supportive of libertarian and pro-environmental policies (cf. Dingler et al. 2018). However, neither governments' positions on the authoritarian-libertarian dimension nor the presence of Green parties could explain women's representation on these issues. Thus, the observed effect of women's higher congruence in contexts with more parliamentary parties does not seem to be explained by Green parties promoting libertarian and environment policies. This could be because the success of Green parties incentivizes mainstream parties to not emphasize environmental issues in order to prevent boosting the challenger's popularity (Abou-Chadi 2016).

However, contagion mechanisms might nevertheless be at work. They might increase the likelihood of the presence of a party with internal institutions and practices that promote the substantive representation of women's preferences, which might 'spread' to other parties. Since the number of women in parliament was controlled for in the analysis, these need to be practices that go beyond increasing the number of women (Matland and Studlar 1996; Caul 2001) - for instance, the promotion of women into leadership roles, women's sections within parties, or rules for alternation between male and female speakers at party meetings, which the German Greens have. Research designs that allow investigating the dynamics of policy responsiveness to public opinion would provide additional valuable insights in this context. 
Further research into the topic should also incorporate policy priorities. One the one hand, this might improve our evaluations of the policy representation of women and men, which arguably improves when they are well represented on the issues they care most about and when their respective policy priorities are high on the agendas of policy-makers. On the other hand, it might help us determine what explains gender disparities in representation. The issues on which women desire policy change might be particularly salient to them, which means that finding out which institutions and other factors increase policy-makers' attention to women's priorities might ultimately help us understand what explains the representation of their positions.

Finally, like much of the research on women's representation, this study compared all women to all men, not least because of data restrictions imposed by the cross-national, multiissue, policy-centered approach. Yet, further research should take individuals' diversity in backgrounds and views into account, as inequality in representation is likely to exist not only between but also among women and men. Intersectional approaches thus have the potential to uncover additional patterns and gaps in representation and enrichen our knowledge about their causes.

\section{REFERENCES}

Abou-Chadi, Tarik (2016). Niche Party Success and Mainstream Party Policy Shifts - How Green and Radical Right Parties Differ in Their Impact. British Journal of Political Science 46: 417-436.

Atchison, Amy (2015). The Impact of Female Cabinet Ministers on a Female-Friendly Labor Environment. Journal of Women, Politics \& Policy 36(4): 388-414. 
Bakker, Ryan, Erica Edwards, Liesbet Hooghe, Seth Jolly et al. (2015). 1999-2014 Chapel Hill Expert Survey Trend File. Version 1.13 Available on chesdata.eu. Chapel Hill, NC: University of North Carolina, Chapel Hill.

Bartels, Larry M. (2008). Unequal Democracy: The Political Economy of the New Gilded Age. New York: Russell Sage Foundation and Princeton University Press.

Baumgartner, Frank R., Christian Breunig, Christoffer Green-Pedersen et al. (2009). Punctuated Equilibrium in Comparative Perspective. American Journal of Political Science 53(3): 603-620.

Bergh, Johannes (2007). Explaining the Gender Gap: A Cross $\square$ National Analysis of Gender Differences in Voting. Journal of Elections, Public Opinion and Parties 17(3): 235-261.

Bernauer, Julian, Nathalie Giger, and Jan Rosset (2015). Mind the Gap: Do Proportional Electoral Systems Foster a More Equal Representation of Women and Men, Poor and Rich? International Political Science Review 36(1): 78-98.

Bevan, Shaun, and Zachary Greene (2016). Looking for the party? The effects of partisan change on issue attention in UK Acts of Parliament. European Political Science Review 8(1): 4972.

Blais, André, and Marc André Bodet (2006). Does Proportional Representation Foster Closer Congruence Between Citizens and Policy Makers? Comparative Political Studies 39: $1243-1262$.

Bormann, Nils-Christian, and Matt Golder (2013). Democratic Electoral Systems around the World, 1946-2011. Electoral Studies 32: 360-369.

Bratton, Kathleen A., and Kerry L. Haynie (1999). Agenda Setting and Legislative Success in State Legislatures: The Effects of Gender and Race. Journal of Politics 61(3): 658-679. 
Bratton, Kathleen A., and Leonard P. Ray (2002). Descriptive Representation, Policy Outcomes, and Municipal Day-Care Coverage in Norway. American Journal of Political Science 46(2): 428-437.

Brooks, Joel E. (1990). The opinion-policy nexus in Germany. Public Opinion Quarterly 54(4): 508-529.

Brunner, Eric, Stephen L. Ross and Ebonya Washington (2013). Does Less Income Mean Less Representation? American Economic Journal: Economic Policy 5(2): 53-76.

Campbell, Rosie (2004). Gender, Ideology and Issue Preference: Is There such a Thing as a Political Women's Interest in Britain? British Journal of Politics \& International Relations 6: 20-44.

Campbell, Rosie, Sarah Childs and Joni Lovenduski (2010). Do Women Need Women Representatives? British Journal of Political Science 40(1): 171-194.

Caul, Miki (2001). Political Parties and Candidate Gender Policies: A Cross-National Study. Journal of Politics 63(4): 1214-1229.

Celis, Karen (2006). Substantive Representation of Women: The Representation of Women's Interests and the Impact of Descriptive Representation in the Belgian Parliament (19001979). Journal of Women, Politics \& Policy 28(2): 85-114.

Childs, Sarah, and Mona Lena Krook (2009). Analysing Women's Substantive Representation: From Critical Mass to Critical Actors. Government and Opposition 44(2): 125-145.

Childs, Sarah, and Julie Withey (2006). The Substantive Representation of Women: The Case of the Reduction of VAT on Sanitary Products. Parliamentary Affairs 59(1): 10-23.

Converse, Philip E. (1964). The Nature of Belief Systems in Mass Publics. In David E. Apter Cowell-Meyers, (ed.), Ideology and Discontent. Ann Arbor: University of Michigan Press, 206-266. 
Cowell-Meyers, Kimberly (2011). A Collarette on a Donkey: The Northern Ireland Women's Coalition and the Limitations of Contagion. Political Studies 59: 411-431.

Cowell-Meyers, Kimberly (2017). The Contagion Effects of the Feminist Initiative in Sweden: Agenda-setting, Niche Parties and Mainstream Parties. Scandinavian Political Studies 40(4): 481-493.

Cox, Gary W. (1997). Making Votes Count: Strategic Coordination in the World's Electoral Systems. Cambridge: Cambridge University Press.

Dahlerup, Drude (1988). From a Small to a Large Minority: Women in Scandinavian Politics. Scandinavian Political Studies 4: 275-298.

de Vries, Catherine E., and Sara B. Hobolt (2012). When Dimensions Collide: The Electoral Success of Issue Entrepreneurs. European Union Politics 13:246-268.

Dingler, Sarah C., Corinna Kroeber and Jessica Fortin-Rittberger (2018). Do parliaments underrepresent women's policy preferences? Exploring gender equality in policy congruence in 21 European democracies. Journal of European Public Policy, doi:10.1080/13501763.2017.1423104.

Dolezal, Martin, Nikolaus Eder, Sylvia Kritzinger and Eva Zeglovits (2013). The Structure of Issue Attitudes Revisited: A Dimensional Analysis of Austrian Voters and Party Elites. Journal of Elections, Public Opinion and Parties 23(4): 423-443.

Döring, Holger, and Philip Manow (2016). Parliaments and governments database (ParlGov): Information on parties, elections and cabinets in modern democracies. Development version. Retrieved from http://www.parlgov.org/ on 25/08/2016.

Enns, Peter K. (2015). Relative Policy Support and Coincidental Representation. Perspectives on Politics 13(4): 1053-1064. 
Esaiasson, Peter, and Sören Holmberg (1996). Representation From Above. Aldershot:

Dartmouth.

Ezrow, Lawrence, and Georgios Xezonakis (2011). Citizen Satisfaction with Democracy and Parties' Policy Offerings. Comparative Political Studies 44: 1152-1178.

Gallagher, Michael (2014). Election indices dataset. Retrieved from http://www.tcd.ie/Political_ Science/staff/michael_gallagher/ElSystems/index.php on 11/05/2017.

Gidengil, Elisabeth, André Blais, Richard Nadeau and Neil Nevitte (2003). Women to the Left? Gender differences in political beliefs and policy preferences. In Manon Tremblay and Linda Trimble (eds.), Women and Electoral Politics in Canada. Don Mills, Ontario: Oxford University Press, 140-159.

Gilens, Martin (2012). Affluence and Influence: Economic Inequality and Political Power in America. New York: Russell Sage Foundation and Princeton University Press.

Golder, Matt (2010). Democratic Electoral Systems around the World, 1946-2000. Electoral Studies 24: 103-20.

Golder, Matt, and Jacek Stramski (2010). Ideological Congruence and Electoral Institutions. American Journal of Political Science 54(1): 90-106.

Golder, Matt, and Gabriella Lloyd (2014). Re-evaluating the Relationship between Electoral Rules and Ideological Congruence. European Journal of Political Research 53(1): 200212.

Greene, Zachary, and Diana O’Brien (2016). Diverse parties, diverse agendas? Female politicians and the parliamentary party's role in platform formation. European Journal of Political Research 55: 435-453.

Griffin, John D., Brian Newman and Christina Wolbrecht (2012). A Gender Gap in Policy Representation in the U.S. Congress? Legislative Studies Quarterly 37(1): 35-66. 
Hayes, Bernadette C. (1997). Gender, feminism and electoral behaviour in Britain. Electoral Studies 16(2): 203-216.

Hobolt, Sara B., and Robert Klemmensen (2008). Government Responsiveness and Political Competition in Comparative Perspective. Comparative Political Studies 41(3): 309-337.

Höhmann, Daniel (2017). Electoral Systems and the Legislative Behavior of Women. Paper presented at the General Conference of the European Political Science Association, Milan, 22-24 June.

Homola, Jonathan (2017). Are Parties Equally Responsive to Women and Men? British Journal of Political Science. doi:10.1017/S0007123417000114.

Htun, Mala, Marina Lacalle and Juan Pablo Micozzi (2013). Does Women's Presence Change Legislative Behavior? Evidence from Argentina, 1983-2007. Journal of Politics in Latin America 5(1): 95-125.

Htun, Mala, and S. Laurel Weldon (2012). The Civic Origins of Progressive Policy Change: Combating Violence against Women in Global Perspective, 1975-2005. American Political Science Review 106(3): 548-569.

Inglehart, Ronald, and Pippa Norris (2000). The Developmental Theory of the Gender Gap: Women's and Men's Voting Behavior in Global Perspective. International Political Science Review 21(4): 441-463.

IPU - Inter-Parliamentary Union (2018). Women in Parliament. Accessed on 26/04/2018 on http://archive.ipu.org/wmn-e/classif-arc.htm.

Keefer, Philip E. (2015). Database of Political Institutions 2015. Retrieved from http://go. worldbank.org/2EAGGLRZ40 on 11/05/2017.

Kittilson, Miki Caul (2008). Representing Women: The Adoption of Family Leave in Comparative Perspective. Journal of Politics 70(2): 323-334 
Kittilson, Miki Caul (2013). Party Politics. In Georgina Waylen et al. (eds.), The Oxford Handbook of Gender and Politics. Oxford: Oxford University Press, 536-553.

Knutsen, Oddbjørn (2001). Social class, sector employment, and gender as party cleavages in the Scandinavian countries: a comparative longitudinal study, 1970-95. Scandinavian Political Studies 24(4): 311-350.

Krook, Mona L., and Leslie Schwindt-Bayer (2013). Electoral Institutions. In Georgina Waylen et al. (eds.), The Oxford Handbook of Gender and Politics. Oxford: Oxford University Press, 554-578.

Kuklinski, James H., and Gary M. Segura (1995). Endogeneity, Exogeneity, Time, and Space in Political Representation: A Review Article. Legislative Studies Quarterly 20(1): 3-21.

Lax, Jeffrey R. and Justin H. Phillips (2012). The Democratic Deficit in the States. American Journal of Political Science 56(1): 148-166.

Lijphart, Arend (1994). Electoral systems and party systems. Oxford, UK: Oxford University Press.

Lipset, Seymour Martin, and Stein Rokkan (1967). Cleavage structures, party systems, and voter alignments. In Seymour Martin Lipset and Stein Rokkan (eds.), Party Systems and Voter Alignments: Cross-National Perspectives. New York: Free Press, 1-64.

Mansbridge, Jane (1999). Should Blacks Represent Blacks and Women Represent Women? A Contingent "Yes". Journal of Politics 61(3): 628-657.

Matland, Richard E., and Donley T. Studlar (1996). The Contagion of Women Candidates in Single-Member District and Proportional Representation Electoral Systems: Canada and Norway. Journal of Politics 58(3): 707-733. 
Matland, Richard E., and Michelle M. Taylor (1997). Electoral System Effects on Women's Representation: Theoretical Arguments and Evidence from Costa Rica. Comparative Political Studies 30(2): 186-210.

Mazur, Amy G. (2002). Theorizing Feminist Policy. Oxford: Oxford University Press.

McAllister, Ian, and Donley T. Studlar (2002). Electoral systems and women's representation: A long $\square$ term perspective, Representation 39(1): 3-14.

Meguid, Bonnie M. (2005). Competition Between Unequals: The Role of Mainstream Party Strategy in Niche Party Success. American Political Science Review 99(3): 347-359.

Monroe, Alan D. (1998). Public Opinion and Public Policy, 1980-1993. Public Opinion Quarterly 62(1): 6-28.

Osborn, Tracy L. (2012). How Women Represent Women: Political Parties, Gender and Representation in the State Legislatures. Oxford: Oxford University Press.

Page, Benjamin I., and Robert Y. Shapiro (1983). Effects of Public Opinion on Policy. American Political Science Review 77(1): 175-190.

Peters, Yvette, and Sander J. Ensink (2015). Differential Responsiveness in Europe: The Effects of Preference Difference and Electoral Participation. West European Politics 38(3): 577 600.

Phillips, Anne (1995). The Politics of Presence. Oxford: Clarendon Press.

Pitkin, Hanna F. (1967). The Concept of Representation. Berkeley: University of California Press.

Poggione Sarah (2004). Exploring gender differences in state legislators' policy preferences. Political Research Quarterly 57(2): 305-314. 
Pratto, Felicia, Lisa M. Stallworth and Jim Sidanius (1997). The gender gap: Differences in political attitudes and social dominance orientation. British Journal of Social Psychology 36: $49-68$.

Rasmussen, Anne, Stefanie Reher and Dimiter Toshkov (forthcoming). The Opinion-Policy Nexus in Europe and the Role of Political Institutions. European Journal of Political Research.

Reher, Stefanie (2015). Explaining Cross-National Variation in the Relationship between Priority Congruence and Satisfaction with Democracy. European Journal of Political Research 54(1): 160-181.

Sawer, Marian (2012). What Makes the Substantive Representation of Women Possible in a Westminster parliament? The Story of RU486 in Australia. International Political Science Review 33(3): 320-335.

Schwindt-Bayer, Leslie A., and William Mishler (2005). An Integrated Model of Women's Representation. Journal of Politics 67(2): 407-428.

Shapiro, Robert Y., and Harpreet Mahajan (1986). Gender Differences in Policy Preferences: A Summary of Trends From the 1960s to the 1980s. Public Opinion Quarterly 50(1): 42-61. Soroka, Stuart N., and Christopher Wlezien (2008). On the Limits to Inequality in Representation. PS: Political Science \& Politics 41(2): 319-327.

Soroka, Stuart N., and Christopher Wlezien (2010). Degrees of Democracy: Politics, Public Opinion, and Policy. New York: Cambridge University Press.

Stetson, Dorothy McBride, and Amy G. Mazur (eds) (1995). Comparative State Feminism. Thousand Oaks, CA: Sage.

Stimson, James A., Michael B. Mackuen and Robert S. Erikson (1995). Dynamic Representation. American Political Science Review 89(3): 543-565. 
Swers, Michele L. (1998). Are Women More Likely to Vote for Women's Issue Bills than Their Male Colleagues? Legislative Studies Quarterly 23(3): 435-448.

Taylor-Robinson, Michelle M., and Roseanna Michelle Heath (2003). Do Women Legislators Have Different Policy Priorities than Their Male Colleagues? Women \& Politics 24(4): 77-101.

Thomas, Sue (1991). The Impact of Women on State Legislative Policies. Journal of Politics 53(4): 958-976.

Thomas, Sue (1994). How Women Legislate. Oxford: Oxford University Press.

Thomassen, Jacques (2012). The Blind Corner of Political Representation. Representation 48(1): $13-27$.

Tremblay, Manon (2003). Women's Representational Role in Australia and Canada: The Impact of Political Context. Australian Journal of Political Science 38(2): 215-238.

Vega Arturo, and Juanita M. Firestone (1995). The effects of gender on congressional behavior and the substantive representation of women. Legislative Studies Quarterly 20(2): 213222.

Verba, Sidney (2003). Would the Dream of Political Equality Turn Out to Be a Nightmare? Perspectives on Politics 1(4): 663-80.

Verba, Sidney, Nancy Burns and Kay L. Schlozman (1997). Knowing and Caring about Politics: Gender and Political Engagement. Journal of Politics 59(4): 1051-1072.

Verba, Sidney, Kay L. Schlozman and Henry E. Brady (1995). Voice and Equality. Cambridge, MA: Harvard University Press.

Wagner, Markus (2012). Defining and Measuring Niche Parties. Party Politics 18:845-864. Wängnerud, Lena (2000). Testing the Politics of Presence: Women's Representation in the Swedish Riksdag. Scandinavian Political Studies 23(1): 67-91. 
Wängnerud, Lena (2009). Women in Parliaments: Descriptive and Substantive Representation. Annual Review of Political Science 12: 51-69.

Wängnerud, Lena (2015). The Principles of Gender-Sensitive Parliaments. New York: Routledge.

Wängnerud, Lena, and Anders Sundell (2012). Do Politics Matter? Women in Swedish Local Elected Assemblies 1970-2010 and Gender Equality in Outcomes. European Political Science Review 4(1): 97-120.

Waylen, Georgina (2007). Engendering Transitions: Women's Mobilization, Institutions and Gender Outcomes. Oxford: Oxford University Press.

Weldon, S. Laurel (2002). Beyond Bodies: Institutional Sources of Representation for Women in Democratic Policymaking. Journal of Politics 64(4): 1153-1174. 


\section{TABLES AND FIGURES}

Table 1. Preference agreement and policy congruence by issue

\begin{tabular}{|c|c|c|c|c|}
\hline & $\begin{array}{c}\text { (a) } \\
\text { Agreement } \\
\text { between the } \\
\text { majorities of } \\
\text { men and } \\
\text { women } \\
\text { (\% of cases) }\end{array}$ & $\begin{array}{l}\text { (b) } \\
\text { Congruence } \\
\text { between the } \\
\text { majority of men } \\
\text { and policy } \\
\text { (\% of cases) }\end{array}$ & $\begin{array}{c}\text { (c) } \\
\text { Congruence } \\
\text { between the } \\
\text { majority of } \\
\text { women and } \\
\text { policy } \\
(\% \text { of cases }) \\
\end{array}$ & $\begin{array}{l}\text { Number of } \\
\text { countries per } \\
\text { issue }\end{array}$ \\
\hline Warnings on alcohol bottles & 100 & 7 & 7 & 27 \\
\hline Animal experiments & 55 & 71 & 58 & 31 \\
\hline Smoking ban & 93 & 71 & 64 & 28 \\
\hline Tobacco vending machines & 78 & 78 & 56 & 27 \\
\hline Embryonic stem cell research & 77 & 74 & 65 & 31 \\
\hline Nuclear power & 56 & 74 & 67 & 27 \\
\hline Minimum wage & 100 & 89 & 89 & 27 \\
\hline Support for caregivers & 100 & 86 & 86 & 28 \\
\hline Detention without charge & 89 & 56 & 44 & 18 \\
\hline Same-sex marriage & 93 & 67 & 59 & 27 \\
\hline Adoption by same-sex couples & 74 & 84 & 84 & 31 \\
\hline Abortion & 100 & 74 & 74 & 27 \\
\hline Citizenship & 100 & 40 & 40 & 20 \\
\hline Progressive tax & 100 & 94 & 94 & 16 \\
\hline Income and pension & 94 & 56 & 63 & 16 \\
\hline Refugees and work & 95 & 43 & 38 & 21 \\
\hline Online voting & 75 & 38 & 63 & 16 \\
\hline Military in Afghanistan & 80 & 87 & 93 & 15 \\
\hline Mandatory retirement & 100 & 47 & 47 & 30 \\
\hline Plastic waste disposal & 100 & 21 & 21 & 28 \\
\hline Total & 87 & 63 & 60 & 491 \\
\hline
\end{tabular}


Table 2. Preference agreement and policy congruence by country

\begin{tabular}{|c|c|c|c|c|}
\hline & $\begin{array}{l}\text { (a) } \\
\text { Agreement } \\
\text { between the } \\
\text { majorities of men } \\
\text { and women } \\
\text { (\% of cases) } \\
\end{array}$ & $\begin{array}{l}\text { (b) } \\
\text { Congruence } \\
\text { between the } \\
\text { majority of men } \\
\text { and policy } \\
(\% \text { of cases }) \\
\end{array}$ & $\begin{array}{c}(\mathrm{c}) \\
\text { Congruence } \\
\text { between the } \\
\text { majority of } \\
\text { women and policy } \\
\text { (\% of cases) }\end{array}$ & $\begin{array}{l}\text { (d) } \\
\text { Number of } \\
\text { issues per } \\
\text { country }\end{array}$ \\
\hline Austria & 95 & 79 & 74 & 19 \\
\hline Belgium & 71 & 41 & 71 & 17 \\
\hline Bulgaria & 93 & 67 & 60 & 15 \\
\hline Croatia & 86 & 71 & 57 & 7 \\
\hline Cyprus & 93 & 71 & 64 & 14 \\
\hline Czech Republic & 82 & 65 & 47 & 17 \\
\hline Denmark & 79 & 53 & 53 & 19 \\
\hline Estonia & 92 & 77 & 85 & 13 \\
\hline Finland & 84 & 63 & 58 & 19 \\
\hline France & 85 & 70 & 65 & 20 \\
\hline Germany & 75 & 60 & 55 & 20 \\
\hline Greece & 100 & 65 & 65 & 17 \\
\hline Hungary & 100 & 65 & 65 & 17 \\
\hline Iceland & 75 & 75 & 50 & 4 \\
\hline Ireland & 95 & 47 & 42 & 19 \\
\hline Italy & 76 & 47 & 47 & 17 \\
\hline Latvia & 94 & 44 & 50 & 16 \\
\hline Lithuania & 100 & 69 & 69 & 13 \\
\hline Luxembourg & 88 & 59 & 47 & 17 \\
\hline Malta & 92 & 69 & 62 & 13 \\
\hline Norway & 73 & 45 & 55 & 11 \\
\hline Poland & 88 & 53 & 53 & 17 \\
\hline Portugal & 90 & 80 & 70 & 20 \\
\hline Romania & 85 & 77 & 62 & 13 \\
\hline Slovakia & 100 & 60 & 60 & 15 \\
\hline Slovenia & 94 & 47 & 41 & 17 \\
\hline Spain & 90 & 65 & 55 & 20 \\
\hline Sweden & 80 & 80 & 80 & 20 \\
\hline Switzerland & 67 & 67 & 33 & 6 \\
\hline Netherlands & 89 & 74 & 74 & 19 \\
\hline UK & 80 & 65 & 65 & 20 \\
\hline Total & 87 & 63 & 60 & 491 \\
\hline
\end{tabular}


Table 3. Opinion-policy congruence among men and women

\begin{tabular}{lccc}
\hline & Men & Women & $\begin{array}{c}\text { Difference in } \\
\text { proportions test }\end{array}$ \\
\cline { 2 - 4 } Share of cases with policy congruence among all cases & $63 \%$ & $60 \%$ & $z=1.05$ \\
& $(310 / 491)$ & $(294 / 491)$ & $p=.294$ \\
Share of cases with policy congruence among cases & $63 \%$ & $37 \%$ & $z=2.87$ \\
with disagreement between men and women & $(39 / 62)$ & $(23 / 62)$ & $p=.004$ \\
Share of cases with policy congruence among cases & $57 \%$ & $33 \%$ & $z=1.79$ \\
where they disagree with the public majority & $(13 / 23)$ & $(13 / 39)$ & $p=.074$ \\
\hline
\end{tabular}


Table 4. Logistic regressions of women's policy congruence

\begin{tabular}{|c|c|c|c|c|c|}
\hline & (1) & (2) & (3) & (4) & $(5)$ \\
\hline Proportion of women & $.04(.04)$ & & & & $.07(.05)$ \\
\hline Government ideology & & $-.39(.32)$ & & & $-.66(.42)$ \\
\hline PR system & & & $-.36(1.09)$ & & $-4.17(1.89)^{*}$ \\
\hline Number of parties & & & & $.74(.29)^{*}$ & $1.18(.46)^{*}$ \\
\hline Response ratio & $-16.93(9.61)$ & $-17.43(9.88)$ & $-16.06(9.67)$ & $-15.63(10.81)$ & $-11.05(10.62)$ \\
\hline Turnout & $-.02(.35)$ & $.13(.33)$ & $.20(.37)$ & $.38(.39)$ & $.39(.48)$ \\
\hline Turnout $^{2}$ & $.00(.00)$ & $-.00(.00)$ & $-.00(.00)$ & $-.00(.00)$ & $-.00(.00)$ \\
\hline Age of democracy & $.00(.01)$ & $.01(.01)$ & $.01(.01)$ & $.01(.01)$ & $-.01(.01)$ \\
\hline Year & $-.23(.11)^{*}$ & $-.12(.11)$ & $-.17(.10)$ & $-.18(.11)$ & $-.04(.14)$ \\
\hline Constant & $16.87(15.65)$ & $-13.32(15.30)$ & $-7.85(16.26)$ & $-.71(17.77)$ & $-3.99(22.40)$ \\
\hline Pseudo R-squared & .20 & .20 & .18 & .28 & .37 \\
\hline $\mathrm{N}$ & 61 & 61 & 61 & 61 & 61 \\
\hline
\end{tabular}


Table 5. Women's and men's policy preferences and policy on issues with disagreement between the majorities of women and men

\begin{tabular}{|c|c|c|c|}
\hline & (a) & (b) & (c) \\
\hline & $\begin{array}{l}\text { Cases (countries) with } \\
\text { majority of women in } \\
\text { favor } 1\end{array}$ & $\begin{array}{l}\text { Cases (countries) with } \\
\text { majority of men in } \\
\text { favor }_{1}\end{array}$ & $\begin{array}{l}\text { Cases (countries) with } \\
\text { policy in place }\end{array}$ \\
\hline Allowing animal experiments & $0 / 14$ & $14 / 14$ & $9 / 14$ \\
\hline Ban on smoking in bars and pubs & $2 / 2$ & $0 / 2$ & $0 / 2$ \\
\hline Ban on tobacco vending machines & $6 / 6$ & $0 / 6$ & $0 / 6$ \\
\hline $\begin{array}{l}\text { Ban on embryonic stem cell } \\
\text { research }\end{array}$ & $7 / 7$ & $0 / 7$ & $2 / 7$ \\
\hline Supporting nuclear power & $0 / 12$ & $12 / 0$ & $7 / 12$ \\
\hline $\begin{array}{l}\text { Allowing detention without } \\
\text { charge without time limit }\end{array}$ & $2 / 2$ & $0 / 2$ & $0 / 2$ \\
\hline Ban on same-sex marriage & $0 / 2$ & $2 / 2$ & $2 / 2$ \\
\hline $\begin{array}{l}\text { Allowing adoption by same-sex } \\
\text { couples }\end{array}$ & $8 / 8$ & $0 / 8$ & $4 / 8$ \\
\hline $\begin{array}{l}\text { Allowing earning an income while } \\
\text { receiving a pension }\end{array}$ & $0 / 1$ & $1 / 1$ & $0 / 1$ \\
\hline Allowing asylum seekers to work & $1 / 1$ & $0 / 1$ & $0 / 1$ \\
\hline Implementing online voting & $0 / 4$ & $4 / 4$ & $0 / 4$ \\
\hline Sending military to Afghanistan & $0 / 3$ & $3 / 3$ & $1 / 3$ \\
\hline
\end{tabular}

${ }_{1}$ The samples only include the cases with disagreement between the majorities of women and men. 
Table 6. Logistic regressions of women's policy congruence with government GAL-TAN position and Green party presence

\begin{tabular}{|c|c|c|c|c|}
\hline & $(1)$ & $(2)$ & (3) & $(4)$ \\
\hline Descriptive representation & $.08(.04)$ & $.07(.05)$ & $.10(.05)$ & $.07(.05)$ \\
\hline Government ideology & $-.65(.49)$ & $-.82(.56)$ & $-.85(.44)$ & $-.66(.46)$ \\
\hline PR system & $-1.77(1.34)$ & $-4.27(1.89)^{*}$ & $-2.90(1.75)$ & $-4.18(2.03)^{*}$ \\
\hline Number of parties (ENPP) & & $1.21(.47)^{*}$ & & $1.18(.49)^{*}$ \\
\hline Government GAL-TAN & $.09(.53)$ & $.28(.61)$ & & \\
\hline Green party in parliament & & & $1.33(1.06)$ & $.01(1.14)$ \\
\hline Response ratio & $-15.92(10.06)$ & $-10.30(11.60)$ & $-14.80(10.27)$ & $-11.04(11.67)$ \\
\hline Turnout & $-.08(.36)$ & $.39(.48)$ & $-.07(.35)$ & $.39(.48)$ \\
\hline Turnout $^{2}$ & $.00(.00)$ & $-.00(.00)$ & $.00(.00)$ & $-.00(.00)$ \\
\hline Age of democracy & $-.00(.01)$ & $-.01(.01)$ & $-.01(.01)$ & $-.01(.01)$ \\
\hline Year & $-.12(.13)$ & $-.02(.14)$ & $-.10(.12)$ & $-.04(.14)$ \\
\hline Constant & $19.77(16.97)$ & $-5.68(22.75)$ & $19.80(17.17)$ & $-3.97(22.46)$ \\
\hline Pseudo R-squared & .25 & .38 & .27 & .37 \\
\hline $\mathrm{N}$ & 61 & 61 & 61 & 61 \\
\hline
\end{tabular}

$* \mathrm{p}<.05, * * \mathrm{p}<.01, * * * \mathrm{p}<.001$ 


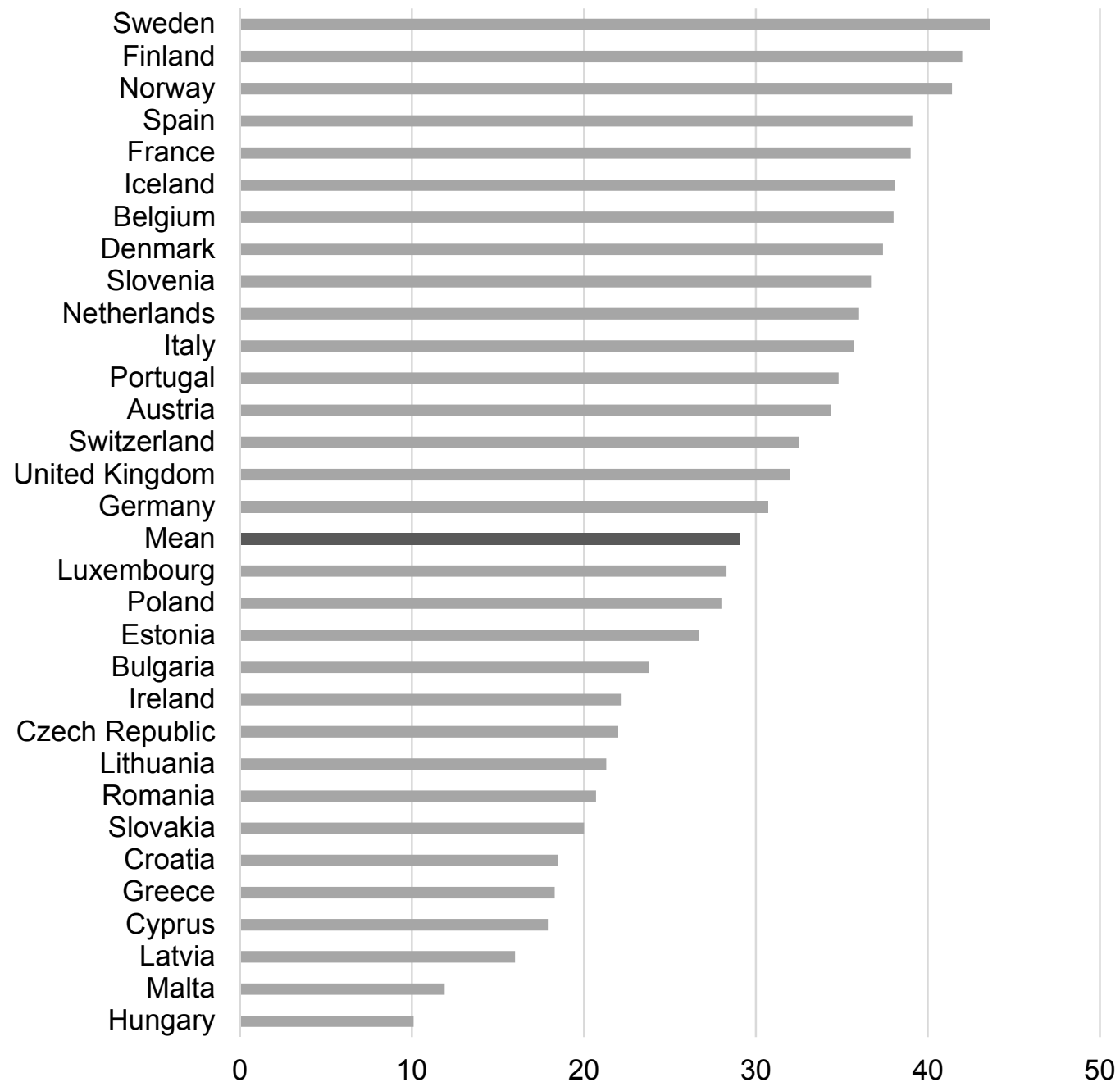

Figure 1. Proportion of seats held by women in national parliaments (single chamber or lower house) in Europe as of April 1, 2018

Source: IPU (2018) 


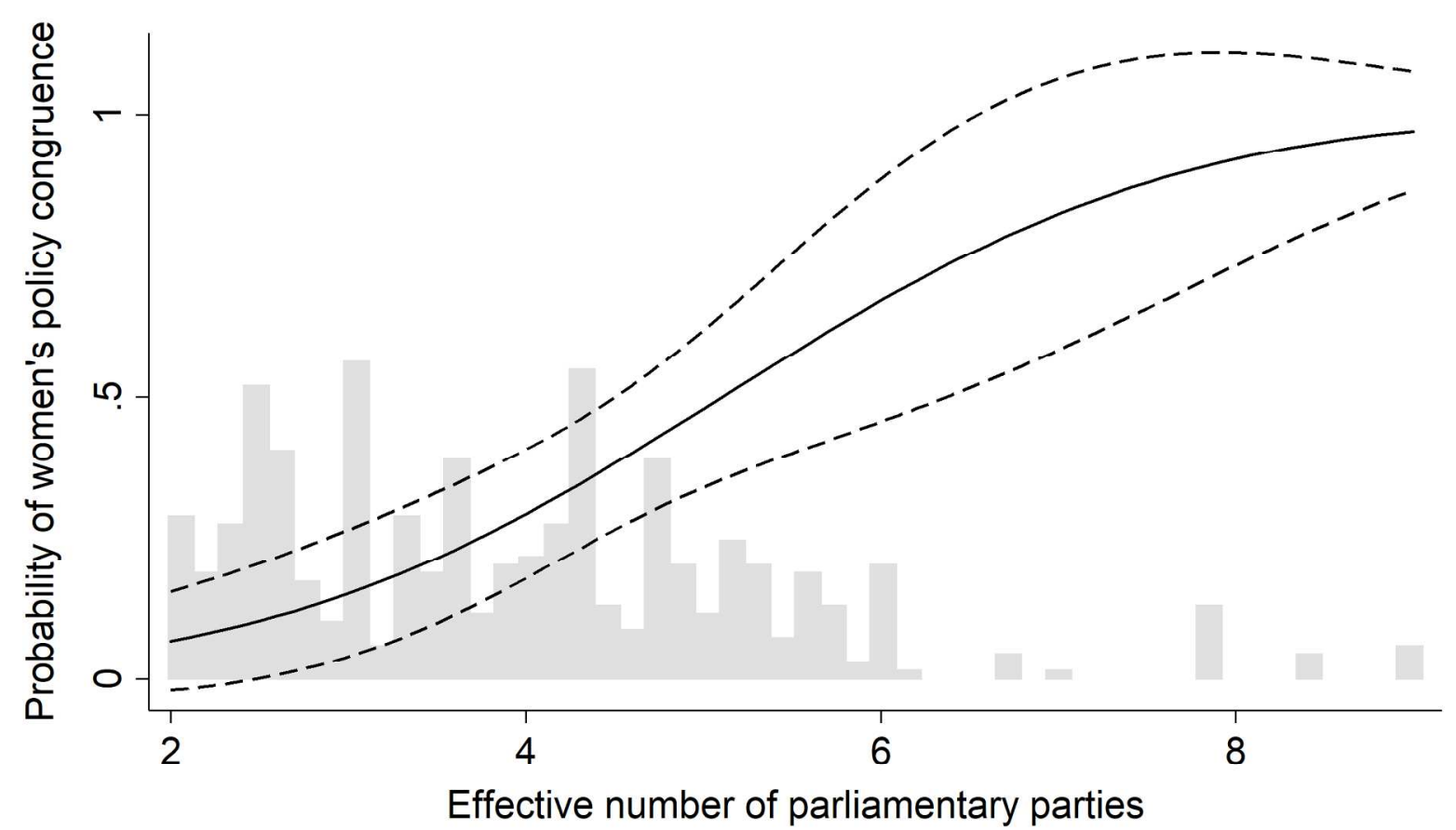

Figure 2. Predicted probabilities of women's policy congruence based on electoral system proportionality (ENPP)

Notes: Probabilities are based on Model 2 and calculated from average marginal effects (all other variables at their observed values). 


\section{SUPPLEMENTARY INFORMATION A}

Table S1. Policy issues, survey questions, year, survey, and number of countries

\begin{tabular}{|c|c|c|c|c|}
\hline Policy issue & Survey item & Year & Survey & $\begin{array}{l}\text { No. of } \\
\text { countries }\end{array}$ \\
\hline $\begin{array}{l}\text { Warnings on } \\
\text { alcohol bottles }\end{array}$ & $\begin{array}{l}\text { "Would you agree or disagree to put warnings on alcohol } \\
\text { bottles with the purpose to warn pregnant women and drivers } \\
\text { of dangers of drinking alcohol?" }\end{array}$ & 2009 & EB 72.3 & 27 \\
\hline $\begin{array}{l}\text { Animal } \\
\text { experiments }\end{array}$ & $\begin{array}{l}\text { "Scientists should be allowed to experiment on animals like } \\
\text { dogs and monkeys if this can help sort out human health } \\
\text { problems" }\end{array}$ & 2010 & EB 73.1 & 31 \\
\hline Smoking ban & $\begin{array}{l}\text { "Are you in favour of smoking bans in the following places? } \\
\text { Bars, pubs and clubs" }\end{array}$ & 2008 & $\begin{array}{l}\text { Flash } \\
\text { EB } 253\end{array}$ & 28 \\
\hline $\begin{array}{l}\text { Tobacco vending } \\
\text { machines }\end{array}$ & $\begin{array}{l}\text { "Banning the sales of tobacco products through vending } \\
\text { machines" }\end{array}$ & 2012 & EB 77.1 & 27 \\
\hline $\begin{array}{l}\text { Embryonic stem } \\
\text { cell research }\end{array}$ & $\begin{array}{l}\text { "Research involving human embryos should be forbidden, } \\
\text { even if this means that possible treatments are not made } \\
\text { available to ill people" }\end{array}$ & 2010 & EB 73.1 & 31 \\
\hline Nuclear power & $\begin{array}{l}\text { "Are you totally in favour, }[\ldots] \text { or totally opposed to energy } \\
\text { production by nuclear power stations?" }\end{array}$ & 2008 & EB 69.1 & 27 \\
\hline Minimum wage & $\begin{array}{l}\text { "A minimum reasonable wage should be guaranteed in (OUR } \\
\text { COUNTRY), even if this would lead to fewer jobs available." }\end{array}$ & 2010 & EB 74.1 & 27 \\
\hline $\begin{array}{l}\text { Support for } \\
\text { caregivers }\end{array}$ & $\begin{array}{l}\text { "The state should pay an income to those who have to give up } \\
\text { working or reduce their working time to care for a dependent } \\
\text { [elderly] person" }\end{array}$ & 2007 & EB 67.3 & 28 \\
\hline $\begin{array}{l}\text { Detention without } \\
\text { charge }\end{array}$ & $\begin{array}{l}\text { "Suppose the government suspected that a terrorist act was } \\
\text { about to happen. Do you think the authorities should have the } \\
\text { right to detain people for as long as they want without putting } \\
\text { them on trial?" }\end{array}$ & $\begin{array}{l}2005- \\
2008\end{array}$ & $\begin{array}{l}\text { ISSP } \\
2006\end{array}$ & 18 \\
\hline $\begin{array}{l}\text { Same-sex } \\
\text { marriage }\end{array}$ & "Same-sex marriages should be prohibited by law." & 2009 & $\begin{array}{l}\text { EES } \\
2009\end{array}$ & 27 \\
\hline $\begin{array}{l}\text { Adoption by } \\
\text { same-sex couples }\end{array}$ & "Homosexual couples should be able to adopt children" & $\begin{array}{l}2008- \\
2009\end{array}$ & $\begin{array}{l}\text { EVS } \\
2008\end{array}$ & 31 \\
\hline Abortion & "Women should be free to decide on matters of abortion." & 2009 & $\begin{array}{l}\text { EES } \\
2009\end{array}$ & 27 \\
\hline Citizenship & $\begin{array}{l}\text { "Children born in [COUNTRY] of parents who are not citizens } \\
\text { should have the right to become [COUNTRY } \\
\text { NATIONALITY] citizens." }\end{array}$ & $\begin{array}{l}2003- \\
2005\end{array}$ & $\begin{array}{l}\text { ISSP } \\
2003\end{array}$ & 20 \\
\hline Progressive tax & $\begin{array}{l}\text { "Do you think people with high incomes should pay a larger } \\
\text { share of their income in taxes than those with low incomes, the } \\
\text { same share, or a smaller share?" }\end{array}$ & $\begin{array}{l}1998- \\
2001\end{array}$ & $\begin{array}{l}\text { ISSP } \\
1999\end{array}$ & 16 \\
\hline $\begin{array}{l}\text { Income and } \\
\text { pension }\end{array}$ & $\begin{array}{l}\text { "Pensioners should be allowed to earn as much as they want on } \\
\text { top of their pension." }\end{array}$ & 2001 & EB 56.1 & 16 \\
\hline $\begin{array}{l}\text { Refugees and } \\
\text { work }\end{array}$ & $\begin{array}{l}\text { "While their applications for refugee status are being } \\
\text { considered, people should be allowed to work in } \\
\text { [COUNTRY]" }\end{array}$ & $\begin{array}{l}2002- \\
2003\end{array}$ & ESS 1 & 21 \\
\hline Online voting & "On-line voting should be used for elections and referenda" & 2001 & EB 54.2 & 16 \\
\hline $\begin{array}{l}\text { Military in } \\
\text { Afghanistan }\end{array}$ & "Send [NATIONALITY] troops to fight with the U.S. forces?" & 2001 & $\begin{array}{c}\text { Flash } \\
\text { EB } 114\end{array}$ & 15 \\
\hline $\begin{array}{l}\text { Mandatory } \\
\text { retirement }\end{array}$ & $\begin{array}{l}\text { "Would you say that people should be allowed to continue } \\
\text { working once they have reached the official retirement age, or } \\
\text { should they have to stop working?" }\end{array}$ & 2011 & EB 76.2 & 30 \\
\hline $\begin{array}{l}\text { Plastic waste } \\
\text { disposal }\end{array}$ & $\begin{array}{l}\text { "Disposing of plastic waste in landfill sites should be } \\
\text { prohibited" }\end{array}$ & 2013 & $\begin{array}{l}\text { Flash } \\
\text { EB } 388\end{array}$ & 28 \\
\hline
\end{tabular}


Table S2. Mean degree of policy support among men and women by issue

\begin{tabular}{lcc}
\hline & Proportion of men in support & Proportion of women in support \\
\hline Warnings on alcohol bottles & 0.78 & 0.82 \\
Animal experiments & 0.62 & 0.48 \\
Smoking ban & 0.64 & 0.71 \\
Tobacco vending machines & 0.56 & 0.65 \\
Embryonic stem cell research & 0.41 & 0.46 \\
Nuclear power & 0.55 & 0.38 \\
Minimum wage & 0.69 & 0.68 \\
Support for caregivers & 0.91 & 0.93 \\
Detention without charge & 0.48 & 0.50 \\
Same-sex marriage & 0.52 & 0.45 \\
Adoption by same-sex couples & 0.29 & 0.37 \\
Abortion & 0.85 & 0.86 \\
Citizenship & 0.81 & 0.83 \\
Progressive tax & 0.80 & 0.82 \\
Income and pension & 0.66 & 0.65 \\
Refugees and work & 0.73 & 0.78 \\
Online voting & 0.51 & 0.47 \\
Military in Afghanistan & 0.43 & 0.35 \\
Mandatory retirement & 0.35 & 0.35 \\
Plastic waste disposal & 0.81 & 0.83 \\
\hline Mean & 0.62 & 0.62 \\
\hline
\end{tabular}


Table S3. Policy scales

\begin{tabular}{|c|c|c|}
\hline Issue & Original scale & Binary scale \\
\hline $\begin{array}{l}\text { Warnings on alcoholic drink } \\
\text { bottles }\end{array}$ & $\begin{array}{l}0=\text { no warnings } \\
1=\text { warnings }\end{array}$ & $\begin{array}{l}0=\text { no warnings } \\
1=\text { warnings }\end{array}$ \\
\hline $\begin{array}{l}\text { Experiments on animals like } \\
\text { monkeys and dogs }\end{array}$ & $\begin{array}{l}0=\text { ban on experiments on } \\
\text { monkeys and dogs } \\
1=\text { ban on experiments on great } \\
\text { apes and gibbons } \\
2=\text { ban on experiments with } \\
\text { great apes } \\
3=\text { no ban }\end{array}$ & $\begin{array}{l}0=\text { ban on experiments on any } \\
\text { monkeys and dogs } \\
1=\text { no ban }\end{array}$ \\
\hline Smoking bans in bars and pubs & $\begin{array}{l}0=\text { no ban } \\
1=\text { partial ban with many } \\
\text { exceptions or not enforced } \\
2=\text { partial ban with some } \\
\text { exceptions } \\
3=\text { ban, but separate smoking } \\
\text { rooms (no exceptions for small } \\
\text { premises) } \\
4=\text { complete ban }\end{array}$ & $\begin{array}{l}0=\text { no ban / partial ban with } \\
\text { many exceptions or not } \\
\text { enforced } \\
1=\text { partial ban with some } \\
\text { exceptions / partial ban with } \\
\text { separate smoking rooms / } \\
\text { complete ban }\end{array}$ \\
\hline $\begin{array}{l}\text { Banning of tobacco sale } \\
\text { through vending machines }\end{array}$ & $\begin{array}{l}0=\text { no ban } \\
1=\text { restrictions } \\
2=\text { ban }\end{array}$ & $\begin{array}{l}0=\text { no ban / no ban but } \\
\text { restrictions } \\
1=\text { ban }\end{array}$ \\
\hline Embryonic stem cell research & $\begin{array}{l}0=\text { no ban } \\
1=\text { no ban but restrictive } \\
2=\text { ban but allowed with } \\
\text { imported cells } \\
3=\text { absolute ban }\end{array}$ & $\begin{array}{l}0=\text { no ban / no ban but } \\
\text { restrictive } \\
1=\text { ban but allowed with } \\
\text { imported cells / absolute ban }\end{array}$ \\
\hline Nuclear power & $\begin{array}{l}0=\text { no nuclear energy with no } \\
\text { plans to build or phase-out plan } \\
1=\text { no nuclear energy with no } \\
\text { explicit policy } \\
2=\text { nuclear energy and plan to } \\
\text { continue or none but explicit } \\
\text { plans to build }\end{array}$ & $\begin{array}{l}0=\text { no nuclear energy with no } \\
\text { plans to build / phase-out plan / } \\
\text { no nuclear energy with no } \\
\text { explicit policy } \\
\text { 1=nuclear energy and plan to } \\
\text { continue / no nuclear energy but } \\
\text { explicit plans to build }\end{array}$ \\
\hline Nation-wide minimum wage & $\begin{array}{l}0=\text { no minimum wage } \\
1=\text { industry-wide } \\
2=\text { national or industry-wide } \\
\text { with coverage }>90 \%\end{array}$ & $\begin{array}{l}0=\text { no minimum wage / industry- } \\
\text { wide minimum wage } \\
1=\text { national or industry-wide } \\
\text { with coverage }>90 \%\end{array}$ \\
\hline $\begin{array}{l}\text { State support to care for } \\
\text { dependent persons }\end{array}$ & $\begin{array}{l}0=\text { no support } \\
1=\text { support }\end{array}$ & $\begin{array}{l}0=\text { no support } \\
1=\text { support }\end{array}$ \\
\hline $\begin{array}{l}\text { Detaining terrorist suspects } \\
\text { indefinitely }\end{array}$ & $\begin{array}{l}0=\text { very short detention limit } \\
(<=3 \text { days) } \\
1=\text { short detention limit }(4-10 \\
\text { days) } \\
2=\text { long detention limit }(>10 \\
\text { days) } \\
3=\text { no detention limit }\end{array}$ & $\begin{array}{l}0=\text { detention limit } \\
1=\text { no detention limit }\end{array}$ \\
\hline Same-sex marriage & $\begin{array}{l}0=\text { marriage legalized } \\
1=\text { registered partnership } \\
2=\text { not legalized } \\
3=\text { prohibited }\end{array}$ & $\begin{array}{l}0=\text { marriage legalized } \\
1=\text { registered partnership / not } \\
\text { legalized / prohibited }\end{array}$ \\
\hline $\begin{array}{l}\text { Adoption of children by same- } \\
\text { sex couples }\end{array}$ & $\begin{array}{l}0=\text { not allowed } \\
1=\text { only internal adoption } \\
2=\text { internal and external }\end{array}$ & $\begin{array}{l}0=\text { not allowed / only internal } \\
\text { adoption } \\
1=\text { internal and external }\end{array}$ \\
\hline Abortion & $\begin{array}{l}0=\text { banned } \\
1=\text { only if threat to life of } \\
\text { mother } \\
2=\text { only if threat to health of }\end{array}$ & $\begin{array}{l}0=\text { banned / only if threat to life } \\
\text { or health of mother / only with } \\
\text { social and economic reasons } \\
1=\text { on request }\end{array}$ \\
\hline
\end{tabular}




\begin{tabular}{|c|c|c|}
\hline & $\begin{array}{l}\text { mother } \\
3=\text { for social and economic } \\
\text { reasons } \\
4=\text { on request }\end{array}$ & \\
\hline $\begin{array}{l}\text { Ius soli (citizenship on the basis } \\
\text { of birth in a territory) }\end{array}$ & $\begin{array}{l}0=\text { only foundlings } \\
1=\text { only stateless children } \\
2=\text { only facilitated naturalization } \\
3=\text { double } \text { ius soli } \\
4=\text { weak ius soli } \\
5=\text { strong ius soli } \\
6=\text { unconditional ius soli } \text { at birth }\end{array}$ & $\begin{array}{l}0=\text { only foundlings or stateless } \\
\text { children / facilitated } \\
\text { naturalization } \\
1=\text { double, weak, strong or } \\
\text { unconditional ius soli at birth }\end{array}$ \\
\hline Progressive income tax & $\begin{array}{l}0=\text { regressive tax } \\
1=\text { flat tax } \\
2=\text { progressive tax }\end{array}$ & $\begin{array}{l}0=\text { regressive or flat tax } \\
1=\text { progressive tax }\end{array}$ \\
\hline $\begin{array}{l}\text { The right to earn while } \\
\text { receiving a pension }\end{array}$ & $\begin{array}{l}0=\text { not allowed to earn } \\
1=\text { limit on earnings/penalty } \\
2=\text { unlimited earnings }\end{array}$ & $\begin{array}{l}0=\text { not allowed to earn } / \text { limit on } \\
\text { earnings or penalty } \\
21=\text { unlimited earnings }\end{array}$ \\
\hline Asylum seekers' right to work & $\begin{array}{l}0=\text { not allowed } \\
1=\text { allowed under certain } \\
\text { conditions } \\
2=\text { allowed }\end{array}$ & $\begin{array}{l}0=\text { not allowed / only under } \\
\text { strong conditions } \\
1=\text { allowed under (weak) } \\
\text { conditions / allowed }\end{array}$ \\
\hline On-line voting & $\begin{array}{l}0=\text { no } \\
1=\text { yes }\end{array}$ & $\begin{array}{l}0=\text { no } \\
1=\text { yes }\end{array}$ \\
\hline $\begin{array}{l}\text { Military involvement in } \\
\text { Afghanistan }\end{array}$ & $\begin{array}{l}0=\text { no } \\
1=\text { yes }\end{array}$ & $\begin{array}{l}0=\text { no } \\
1=\text { yes }\end{array}$ \\
\hline Mandatory retirement age & $\begin{array}{l}0=\text { none } \\
1=\text { none, with few exceptions } \\
\text { (e.g. military) } \\
2=\text { for public servants and/or a } \\
\text { considerable no. of professions } \\
\text { based on collective agreements } \\
\text { and/or employers may set one } \\
3=\text { yes }\end{array}$ & $\begin{array}{l}0=\text { none / none with few } \\
\text { exceptions (e.g. military) } \\
1=\text { for public servants and/or a } \\
\text { considerable number of } \\
\text { professions based on collective } \\
\text { agreements and/or employers } \\
\text { may set one / mandatory } \\
\text { retirement age }\end{array}$ \\
\hline $\begin{array}{l}\text { Banning the disposal of plastic } \\
\text { waste in landfills }\end{array}$ & $\begin{array}{l}0=\text { no } \\
1=\text { yes }\end{array}$ & $\begin{array}{l}0=\text { no } \\
1=\text { yes }\end{array}$ \\
\hline
\end{tabular}


Table S4. Response ratio among women and men

\begin{tabular}{lc}
\hline & Response ratio $=\frac{\text { Response rate }_{1} \text { among } \text { women }}{\text { Pesponse rate }}$ among $_{1}$ men \\
\hline Abortion & 1.028 \\
Same-sex marriage & 1.007 \\
Citizenship & 1.006 \\
Warnings on alcohol bottles & 1.001 \\
Support for caregivers & 0.999 \\
Mandatory retirement & 0.998 \\
Animal experiments & 0.997 \\
Progressive tax & 0.995 \\
Smoking ban & 0.994 \\
Tobacco vending machines & 0.990 \\
Adoption by same-sex couples & 0.990 \\
Embryonic stem cell research & 0.990 \\
Plastic waste disposal & 0.982 \\
Income and pension & 0.980 \\
Military in Afghanistan & 0.978 \\
Minimum wage & 0.975 \\
Refugees and work & 0.966 \\
Detention without charge & 0.961 \\
Online voting & 0.950 \\
Nuclear power & 0.944 \\
\hline Total & 0.988 \\
\hline "nesponse rate refers to proportion of responses in favor or against a policy as opposed to & \\
&
\end{tabular}

Table S5. Logistic regressions of women's policy congruence with different measures of electoral system proportionality

\begin{tabular}{|c|c|c|c|c|}
\hline & \multicolumn{2}{|c|}{ Average district magnitude } & \multicolumn{2}{|c|}{ Gallagher Index } \\
\hline & $(1)$ & $(2)$ & (3) & (4) \\
\hline Descriptive representation & & $.02(.04)$ & & $.06(.06)$ \\
\hline Government ideology (right-wing) & & $-.30(.35)$ & & $-.46(.38)$ \\
\hline Average district magnitude & $.00(.01)$ & $-.00(.01)$ & & \\
\hline Gallagher Index & & & $-.03(.07)$ & $.15(.12)$ \\
\hline Number of parties (ENPP) & & $.69(.32)^{*}$ & & $.81(.35)^{*}$ \\
\hline Response ratio & $-16.74(9.53)$ & $-16.17(11.09)$ & $-16.97(9.59)$ & $-15.71(11.16)$ \\
\hline Turnout & $.15(.34)$ & $.29(.44)$ & $.16(.33)$ & $.07(.48)$ \\
\hline Turnout $^{2}$ & $-.00(.00)$ & $-.00(.00)$ & $-.00(.00)$ & $-.00(.00)$ \\
\hline Age of democracy & $.01(.01)$ & $.01(.01)$ & $.01(.01)$ & $-.00(.01)$ \\
\hline Year & $-.18(.10)$ & $-.14(.13)$ & $-.19(.11)$ & $-.09(.13)$ \\
\hline Constant & $10.50(14.94)$ & $4.21(20.12)$ & $10.80(14.79)$ & $9.92(21.09)$ \\
\hline Pseudo R-squared & .18 & .29 & .18 & .31 \\
\hline $\mathrm{N}$ & 61 & 61 & 61 & 61 \\
\hline
\end{tabular}

$* \mathrm{p}<.05, * * \mathrm{p}<.01, * * * \mathrm{p}<.0005$ 


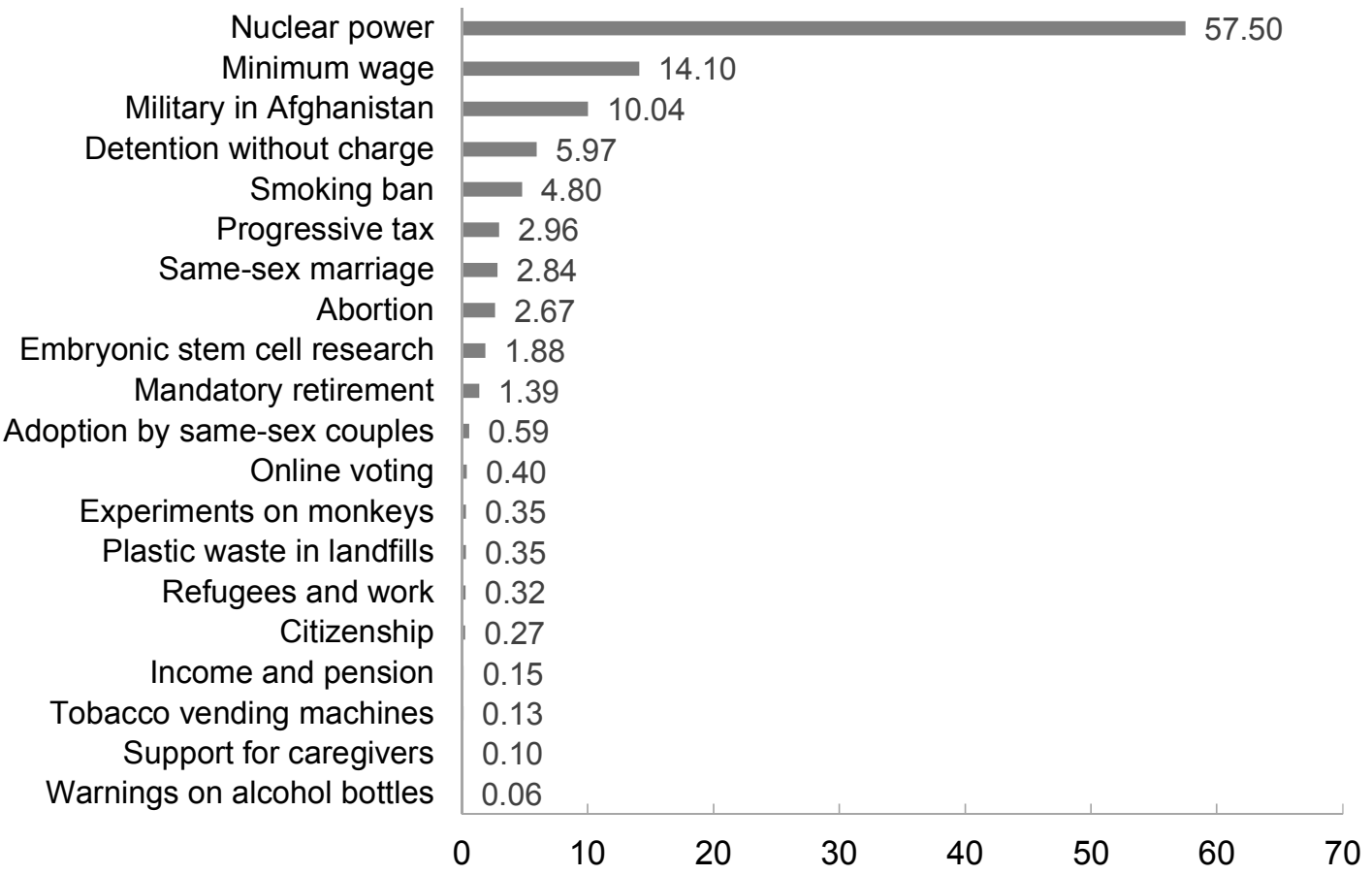

Figure S1. Issue salience based on proportion of Financial Times articles on Europe 

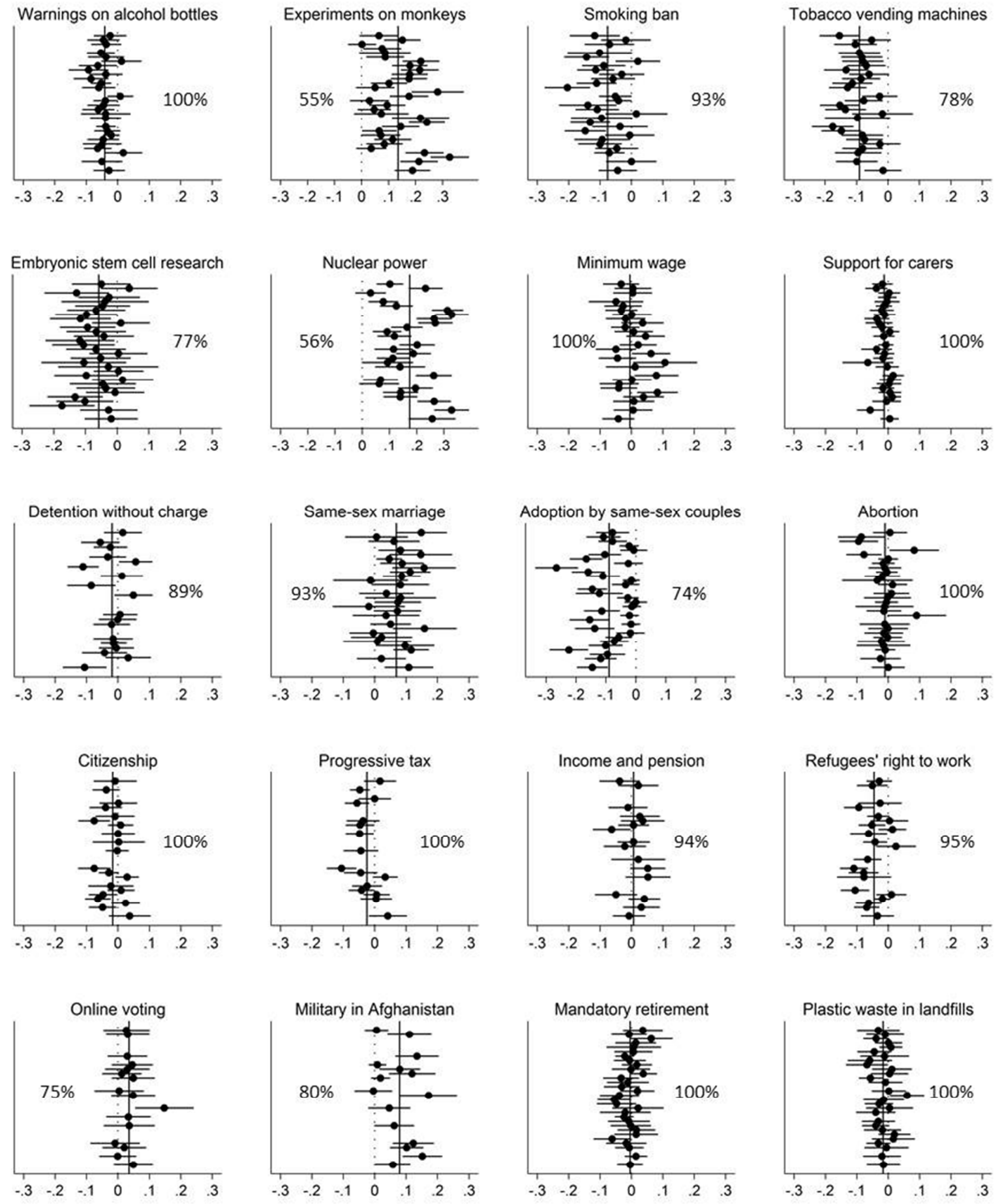

Figure S2. Differences in policy support between men and women across issues

Notes: The dots indicate differences in the proportions of policy support between men and women in a country, with positive values indicating higher support amongst men. The error bars represent $95 \%$ confidence intervals. The percentage of countries with majority agreement between men and women is indicated. 


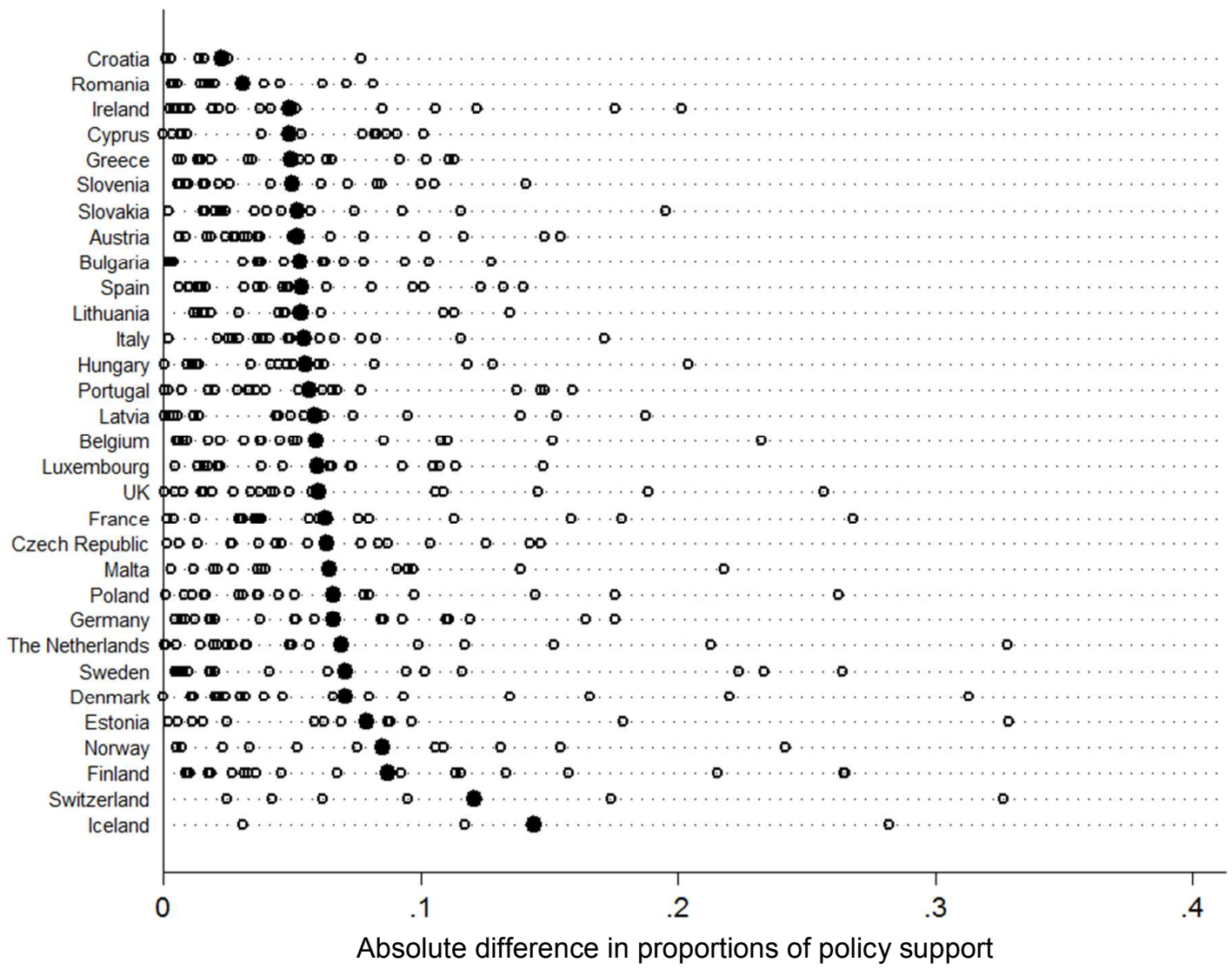

Figure S3. Differences in policy support between men and women across countries

Notes: The hollow circles indicate absolute differences in the proportions of policy support between men and women on each issue. The dots indicate the mean difference in a country. 


\section{SUPPLEMENTARY INFORMATION B: Policy mapping procedure}

The policy measure reflects whether a policy was in place or not in a country at the point in time when the survey including the respective item on respondent opinion on the issue was conducted. The data on the state of policy was collected by one of the authors and a trained research assistant following the Guidelines for Mapping Policy. The process started by picking a policy issue at random from the pool of issues for which public opinion survey questions were identified which met the selection criteria (see article). After determining the countries and time period in which the survey was conducted, the coders conducted research and wrote a description of the issue, delineating the debate and the policy issue to which the survey question refers. Part of this step was to determine whether policies at the EU level existed at the time. If they did, the issue was dropped and replaced by another randomly selected issue from the pool.

If there was no EU policy, the policy in place at the time in each country with available survey data was determined based on various sources that were found to provide reliable information, including official government documents (e.g. websites and press releases), legal documents, academic publications, newspaper articles, publications and websites of international organizations including the EU, non-governmental organizations etc., and interviews with experts on the issue. Information obtained from one source were to be verified by another source if possible. If sufficient information could not be found, the issue was dropped and replaced. Based on the policies found across countries, a unique ordinal policy scale was developed for each issue. These scales, listed in Table S3 (SI A), were subsequently collapsed into binary scales which match the survey question and hence the expressed public support as closely as possible.

For example, the survey question on support for nuclear energy was "Are you totally in favour, fairly in favour, fairly opposed or totally opposed to energy production by nuclear power stations?" (Eurobarometer 69.1; interview period: 18-22/02/2008). The research revealed cross-country variation in both the presence of nuclear power plants and policies for the future. Examples for the sources for this issue include the websites of the European Nuclear Safety Regulators Group (ENSREG) ${ }^{1}$, the World Nuclear Association ${ }^{2}$, the Nuclear Threat Initiative ${ }^{3}$, and the German Ministry for the Environment, Nature Conservation and

\footnotetext{
${ }^{1}$ www.ensreg.eu

${ }^{2}$ www.world-nuclear.org

${ }^{3}$ www.nti.org
} 
Nuclear Safety ${ }^{4}$. On the basis of the presence of plants and government policies, a three-point ordinal scale was developed. Countries with no nuclear energy plants and plans not to build any as well as countries with plants but a phase-out plan in place were coded as not having a pro-nuclear energy policy in place. Countries with no plants and no specific plans to build or to abstain from building plants were coded as having the policy partially in place. Countries with nuclear energy plants and no phase-out plan as well as countries currently without nuclear energy plants but plans to build were coded as having pro-nuclear energy policy in place. This three-point scale was then collapsed into a binary scale by coding the 'partial policy' category as 'no policy', as these countries neither had nuclear energy plants nor explicit plans to build any.

\footnotetext{
${ }^{4}$ www.bmu.de/en
} 


\section{SUPPLEMENTARY INFORMATION C: Regressing policy on public opinion}

An alternative way of assessing the link between public policy and public opinion is, instead of measuring congruence between policy and the majority preferences, to estimate the relationship between the degree of public policy support and the likelihood of policy being in place (cf. Lax and Phillips 2012). Models 1 and 2 in Table S7 show the results of multilevel logit models with issues at level 2, regressing policy on support among men and women, respectively. We find that policy is more likely to be in place the stronger the support among both men and women. However, we cannot compare the sizes of the coefficients of logit models. Thus, I also estimate equivalent multilevel linear models (Models 3 and 4), which show that the coefficient of men's policy support is larger than that of women's support. I also estimate a multilevel logit model that includes both support measures. While this is likely problematic given the very high collinearity between them $(r=.93)$, it strengthens the conclusion that the likelihood of policy is more strongly related to men's policy support than women's. This confirms the conclusion derived from the analysis of majority congruence.

Table S7. Multilevel linear and logistic regressions of policy on the degree of policy support among women and men

\begin{tabular}{|c|c|c|c|c|c|}
\hline & \multicolumn{2}{|l|}{ (1) } & \multicolumn{2}{|c|}{ (3) (4) } & \multirow{2}{*}{$\begin{array}{c}(5) \\
\text { Multilevel } \\
\text { logit } \\
\text { regression }\end{array}$} \\
\hline & Multilevel lo & yit regression & Multilev & ar regression & \\
\hline Men's support & $4.44(.81)^{* * *}$ & & $.77(.12)^{* *}$ & & $5.01(2.22)^{*}$ \\
\hline Women's support & & $3.94(.78) * * *$ & & $.66(.12)^{* * *}$ & $-.59(2.13)$ \\
\hline Constant & $-2.93(.63)^{* * *}$ & $-.63(.63)^{* * *}$ & $.00(.10)$ & $.07(.10)$ & $-2.92(.63)^{* * *}$ \\
\hline Intercept variance & $2.40(.99)$ & $2.76(1.13)$ & $.07(.02)$ & $.08(.03)$ & $2.35(.99)$ \\
\hline Deviance & 525 & 530 & 547 & 553 & 524 \\
\hline N level 1 (level 2) & $491(20)$ & $491(20)$ & $491(20)$ & $491(20)$ & $491(20)$ \\
\hline
\end{tabular}

